\title{
Diplatinum(II) Catecholate of Photoactive Boron-Dipyrromethene for Lysosome-Targeted Photodynamic Therapy in Red Light
}

Vanitha Ramu, ${ }^{\dagger}$ Srishti Gautam, ${ }^{\dagger}$ Paturu Kondaiah, ${ }^{+*}$ and Akhil R. Chakravarty. ${ }^{\dagger *}$ 


\section{$\underline{\text { Table of Contents }}$}

\section{Experimental Section}

Scheme S1. Synthetic scheme for the ligand $\mathrm{H}_{4} \mathrm{Dcrb}$

Scheme S2. Synthetic scheme for the complex DP

Figure S1. Mass spectrum of ligand $\mathrm{H}_{4} \mathrm{Dcrb}$ in $\mathrm{MeOH}$

Figure S2. Mass spectrum of complex DP in $\mathrm{MeOH}$

Figure S3. ${ }^{1} \mathrm{H}$ and ${ }^{11} \mathrm{~B}$ NMR spectra of ligand $\mathrm{H}_{4}$ Dcrb in DMSO- $\mathrm{d}_{6}$

Figure S4. ${ }^{13} \mathrm{C}$ NMR spectrum of ligand $\mathrm{H}_{4}$ Dcrb in DMSO- $\mathrm{d}_{6}$

Figure S5. ${ }^{1} \mathrm{H}$ and ${ }^{11} \mathrm{~B}$ NMR spectra of complex DP in DMSO- $\mathrm{d}_{6}$

Figure S6. Unit cell packing diagram of the ligand $\mathrm{H}_{4} \mathrm{Dcrb}$

Figure S7. H-bonding involving the lattice water molecules and the ligand $\mathrm{H}_{4} \mathrm{Dcrb}$

Figure S8. Time dependent UV-Vis spectra of complexes DP and $\mathrm{H}_{4}$ Dcrb in dark and light in $10 \%$ DMSO/DMEM solution

Figure S9. Time dependent ${ }^{1} \mathrm{H}$ NMR spectra of the complex DP and ligand $\mathrm{H}_{4} \mathrm{Dcrb}$ in dark and light $(600-720 \mathrm{~nm})$ in DMSO-d $\mathrm{d}_{6}$

Figure S10. Time dependent ESI-mass spectra of the complex DP and ligand $\mathrm{H}_{4} \mathrm{Dcrb}$ in dark and light (600-720 nm) in $\mathrm{MeOH} / \mathrm{H}_{2} \mathrm{O}$

Figure S11. Cell viability plots as obtained from the MTT assay of the complex CP

Figure S12. Cell viability plots as obtained from the MTT assay of the complex DP

Figure S13. Cell viability plots as obtained from the MTT assay of the ligand $\mathrm{H}_{4} \mathrm{Dcrb}$

Figure S14. Cell viability plots (chemotherapy) as obtained from the MTT assay of the DP and $\mathrm{H}_{4} \mathrm{Dcrb}$

Figure S15. Cellular uptake plots of $\mathrm{H}_{4}$ Dcrb in A549 cells

Figure S16. Cellular uptake plots of DP and $\mathrm{H}_{4}$ Dcrb in HPL1D cells

Figure S17. The generation of cellular ROS in A549 cells by DCFDA assay with $\mathrm{H}_{4} \mathrm{Dcrb}$ 
Figure S18. The generation of cellular ROS by DCFDA assay with DP and $\mathrm{H}_{4}$ Dcrb in HPL1D cells and CP in A549 cells

Figure S19. The generation of singlet oxygen in A549 cells by DPBF assay with DP

Figure S20. The generation of singlet oxygen in A549 cells by DPBF assay with $\mathrm{H}_{4} \mathrm{Dcrb}$

Figure S21. CLSM images of A549 cells incubated with DP and $\mathrm{H}_{4}$ Dcrb along with MTG

Figure S22. Acridine orange staining of A549 cells with treatment of $\mathrm{H}_{4} \mathrm{Dcrb}$

Table S1. Selected crystallographic data for the ligand $\mathrm{H}_{4} \mathrm{Dcrb}$

Table S2. Selected bond distances $(\AA)$ and angles $\left(^{\circ}\right)$ for the ligand $\mathrm{H}_{4} \mathrm{Dcrb}$

Table S3. Optimized coordinates of the complex DP as obtained from the DFT calculations

Table S4. Selected bond distances $(\AA)$ and angles $\left(^{\circ}\right)$ for the complex DP as obtained from the DFT calculations. 


\section{Methods for Cellular Experiments.}

MTT Assay. The 3-(4,5-dimethylthiazol-2-yl)-2,5-diphenyltetrazolium bromide (MTT) assay was used for the photocytotoxicity of the complexes. ${ }^{\mathrm{S} 1}$ In this assay, the mitochondrial dehydrogenases of viable cells cleaved the tetrazolium rings of MTT forming dark purple insoluble formazan crystals that were soluble in DMSO and was quantified from spectral measurements. Approximately, 8000 cells of HeLa (human cervical cancer), MDA-MB231 (multidrug resistant human epithelial cell line), A549 (human lung adenocarcinoma cell line) and HPL1D (immortalized human lung epithelial cell line) were plated separately in two different 96 wells culture plate and incubated with various concentrations of DP and $\mathrm{H}_{4} \mathrm{Dcrb}$ from 0.2 to 100 $\mu \mathrm{M}$ in $1 \% \mathrm{DMSO} /$ Dulbecco's modified Eagle's medium (DMEM) for $4 \mathrm{~h}$ in the dark. After $4 \mathrm{~h}$ of incubation, the media containing compounds was removed and replaced with DPBS buffer for one set of the cells which were exposed to red light $\left(\lambda=600-720 \mathrm{~nm}\right.$, light dose $\left.=30 \mathrm{~J} \mathrm{~cm}^{-2}\right)$, using Waldmann PDT $1200 \mathrm{~L}$, whereas the other set was kept in the dark for the same time period using standard protocols. After exposure to light, DPBS was removed and replaced with fresh medium and incubation was continued for a further period of $16 \mathrm{~h}$ in dark for the plate thus making the total incubation time of $\sim 21 \mathrm{~h}$. After the incubation period, $5 \mathrm{mg} \mathrm{mL}^{-1}$ of MTT (20 $\mu \mathrm{L}$ ) was added to each well and incubated for an additional $3 \mathrm{~h}$. The media was removed entirely from the wells and then DMSO $(200 \mu \mathrm{L})$ was added and spectral measurement was taken at 570 $\mathrm{nm}$ using TECAN microplate reader. Cytotoxicity of the complexes was measured as the percentage ratio of the absorbance of the treated cells to the untreated controls. $\mathrm{The}^{\mathrm{I}} \mathrm{C}_{50}$ values were determined by nonlinear regression analysis (Graph Pad Prism 6). Data were obtained by using three independent sets of experiments done in triplicate for each concentration. 
Cellular Localization. By using confocal microscopy the intracellular localization of the fluorescent complex DP and ligand $\mathrm{H}_{4} \mathrm{Dcrb}(5 \mu \mathrm{M})$ in 1\% DMSO/DMEM was investigated by confocal microscopy (Zeiss LSM 880 with Airyscan) using an oil immersion lens having a magnification of $63 \mathrm{X}$. About $5 \times 10^{4}$ cells were plated on glass cover slips in 12 well tissue culture plates and incubated at $37{ }^{\circ} \mathrm{C}$ and $5 \% \mathrm{CO}_{2}$ atmosphere for $24 \mathrm{~h}$. Cells were then treated with the complexes for $4 \mathrm{~h}$ in dark and fixed. Cells were later incubated with DAPI $(1 \mathrm{mg} / \mathrm{mL})$ for 5 min to stain the nucleus. The cover slips were subjected to confocal microscopy after being mounted on slides. Similar procedure was used for sub-cellular localization without any prior fixation. Live cells were stained with Lysotracker ${ }^{\circledR}$ Green (LTG, $\left.0.1 \mu \mathrm{M}\right)$, Mitotracker ${ }^{\circledR}$ Green (MTG, $0.1 \mu \mathrm{M}$ ) and incubated for $45 \mathrm{~min}$ at room temperature and then observed under microscope. Multiple images were recorded, and experiments were done in duplicates to confirm the results.

DCFDA Study. Cellular reactive oxygen species (ROS) was detected by 7'-dichlorofluorescein diacetate (DCFDA) assay. ${ }^{\mathrm{S} 2}$ Cellular ROS oxidizes cell permeable DCFDA generating a fluorescent DCF having emission maxima at $528 \mathrm{~nm}$. The percentage population of cells generating ROS was determined by flow cytometry analysis. A549 cells were incubated with the compounds at their $\mathrm{IC}_{50}$ values [DP $(0.5 \mu \mathrm{M})$ and $\left.\mathrm{H}_{4} \operatorname{Dcrb}(2 \mu \mathrm{M})\right]$ for $4 \mathrm{~h}$ and then irradiated with red light for $40 \min \left(\lambda=600-720 \mathrm{~nm}\right.$, light dose $\left.=30 \mathrm{~J} \mathrm{~cm}^{-2}\right)$ using Waldmann PDT $1200 \mathrm{~L}$. The cells were harvested by trypsinization and a single cell suspension was prepared. The cells were subsequently treated with $1 \mu \mathrm{M}$ DCFDA (solution prepared with DMSO) in dark for 20 min at room temperature. The distribution of DCFDA stained A549 cells was obtained by flow cytometry in the FL-1 channel. 
Cellular Uptake Studies by FACS. Cellular uptake of the fluorescent complex DP and ligand $\mathrm{H}_{4} \mathrm{Dcrb}$ was studied in A549 cells by FACS analysis. The cells were incubated with $1 \mu \mathrm{M}$ of the compounds for different time periods as $2,4,5$ and $6 \mathrm{~h}$ in the dark. The cells were harvested by trypsinization and a single cell suspension was prepared. The distribution of complex stained A549 cells was obtained by flow cytometry in the APC-Cy7-A channel.

Cellular Uptake Mechanism Studies by Confocal Microscopy. A549 cells (about 5 x $10^{4}$ ) were plated on glass cover slips in 12 well tissue culture plates and incubated at $37{ }^{\circ} \mathrm{C}$ and $5 \%$ $\mathrm{CO}_{2}$ atmosphere for $24 \mathrm{~h}$. Then the cells were incubated with DP and $\mathrm{H}_{4} \mathrm{Dcrb}(5 \mu \mathrm{M})$ at 4 and 37 ${ }^{\circ} \mathrm{C}$ for $4 \mathrm{~h}$. For confocal microscopy analysis, the cells were then washed three times with PBS and visualized by confocal microscopy (Zeiss LSM 880 with Airyscan) with an oil immersion lens having a magnification of $63 \mathrm{X}$. Emission data were collected at $660 \pm 30 \mathrm{~nm}$ upon excitation at $633 \mathrm{~nm}$.

pH-Dependent Emission. The pH-dependent emission of complex DP in A549 cells was measured. About $5 \times 10^{4}$ A549 cells were plated on glass cover slips in 12 well tissue culture plates and incubated at $37{ }^{\circ} \mathrm{C}$ and $5 \% \mathrm{CO}_{2}$ atmosphere for $24 \mathrm{~h}$. The cells were incubated with DP $(5 \mu \mathrm{M})$ for $4 \mathrm{~h}$ at $37^{\circ} \mathrm{C}$. The media was removed and the cells were then incubated with nigericin $(20 \mathrm{pM})$ in disodium hydrogen phosphate/citric acid buffer solutions $(\mathrm{pH}$ 4.0, 7.0 and 8.0) for $10 \mathrm{~min}$. The cells were visualized immediately by confocal microscopy (Zeiss LSM 880 with Airyscan) with an oil immersion lens having a magnification of 63X. Emission was collected at $660 \pm 30 \mathrm{~nm}$ upon excitation at $633 \mathrm{~nm}$.

Annexin V/Propidium Iodide Double Staining Assay. About 3 x $10^{5}$ A549cells were plated in 6 well plates and grown for $24 \mathrm{~h}$. Cells were treated with both the complex DP and ligand 
$\mathrm{H}_{4} \mathrm{Dcrb}$ for $4 \mathrm{~h}$. One of the plates was exposed to photo-irradiation (400-700 nm, $1 \mathrm{~h}$ exposure) in DPBS with subsequent addition of fresh media. The cells were further incubated for $19 \mathrm{~h}$, trypsinized and washed with DPBS twice. The cells were resuspended in $400 \mu \mathrm{L}$ of $1 \mathrm{X}$ binding buffer and $1 \mu \mathrm{L}$ of annexin V-FITC and $2 \mu \mathrm{L}$ of PI were added to each cell suspension. These tubes were then incubated at room temperature for $20 \mathrm{~min}$ in dark. The fluorescence of the cells was measured immediately with a flow cytometer. Cells that were early in the apoptotic process were stained with the annexin V-FITC alone. Live cells showed no staining by either PI or annexin V-FITC. Late apoptotic cells were stained by both PI and annexin V-FITC. The dead cells were only stained by PI.

X-ray Crystallographic Procedure. The crystal structure of ligand $\mathrm{H}_{4} \mathrm{Dcrb}$ was obtained by single-crystal X-ray diffraction method. The deep blue colored rectangular block crystals of $\mathrm{H}_{4}$ Dcrb were obtained from vapor diffusion of hexane into $\mathrm{CH}_{2} \mathrm{Cl}_{2}$ and methanol mixture. The crystal was mounted on loop with paratone oil. All the intensity and geometric data were collected at a scan speed of $5 \mathrm{~s}$ frame $^{-1}$ by an automated Bruker SMART APEX CCD diffractometer having a fine focus $1.75 \mathrm{~kW}$ sealed-tube Mo-Ka X-ray source $(\lambda=0.71073 \AA)$ with increasing $\omega$ (width of $0.3^{\circ}$ per frame). Intensity data were collected using the $\omega-2 \theta$ scan mode and then corrected for Lorentz-polarization and absorption effects. ${ }^{\mathrm{S} 3}$ The structure was solved and refined by using the WinGx suite of programs (version 1.63.04a) by the SHELXL2013 method. The non-hydrogen atoms were refined with anisotropic displacement coefficients, and their coordinates were permitted to ride on their respective carbon atoms. Atomic positions for all the atoms, anisotropic thermal parameters for all the non-hydrogen atoms and isotropic thermal parameters for all the hydrogen atoms were included in the final refinement. ORTEP 
was used to obtain the perspective view. ${ }^{\mathrm{S} 4}$ Selected crystallographic parameters, bond distances and angles data are given in Tables S1 and S2 (vide Supporting Information).

Materials. $\mathrm{K}_{2} \mathrm{PtCl}_{4}$ was obtained from Arora Matthey (India). Mito-Tracker Green FM (MTG), Lyso-Tracker Green FM and DAPI (4',6-diamidino-2-phenylindole) were from Invitrogen (USA). All other reagents and chemicals were sourced from S. D. Fine Chemicals (India) and Sigma-Aldrich (USA).

Theoretical Calculations. The geometries of the complexes were initially optimized [basis sets] by B3LYP/LANL2DZ level of theory calculations. ${ }^{\text {S5 }}$ 


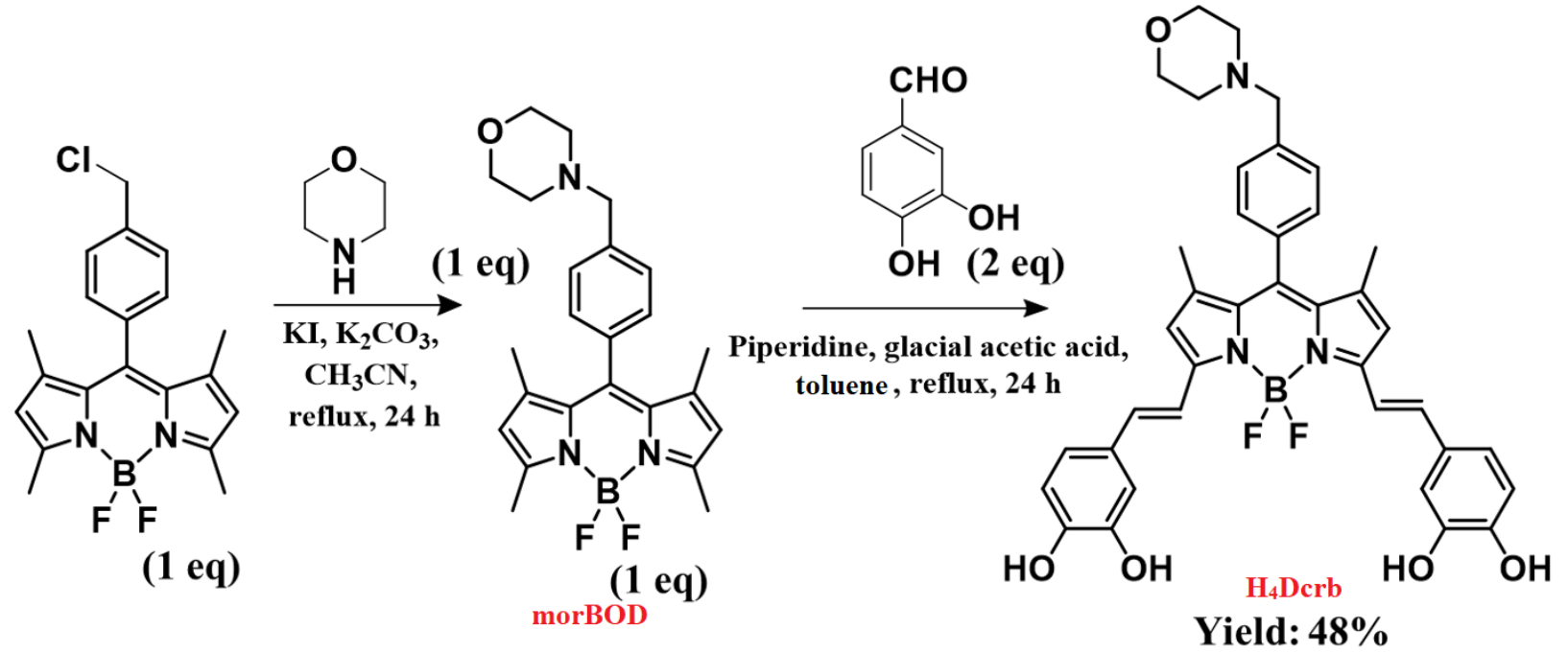

Scheme S1. Synthetic scheme of the ligand $\mathrm{H}_{4}$ Dcrb with IUPAC name 4,4'-((1E,1'E)-(5,5-difluoro-1,9dimethyl-10-(4-(morpholinomethyl)phenyl)-5H-414,514-dipyrrolo[1,2-c:2',1'-f][1,3,2]diazaborinine-3,7diyl)bis(ethene-2,1-diyl))bis(benzene-1,2-diol).

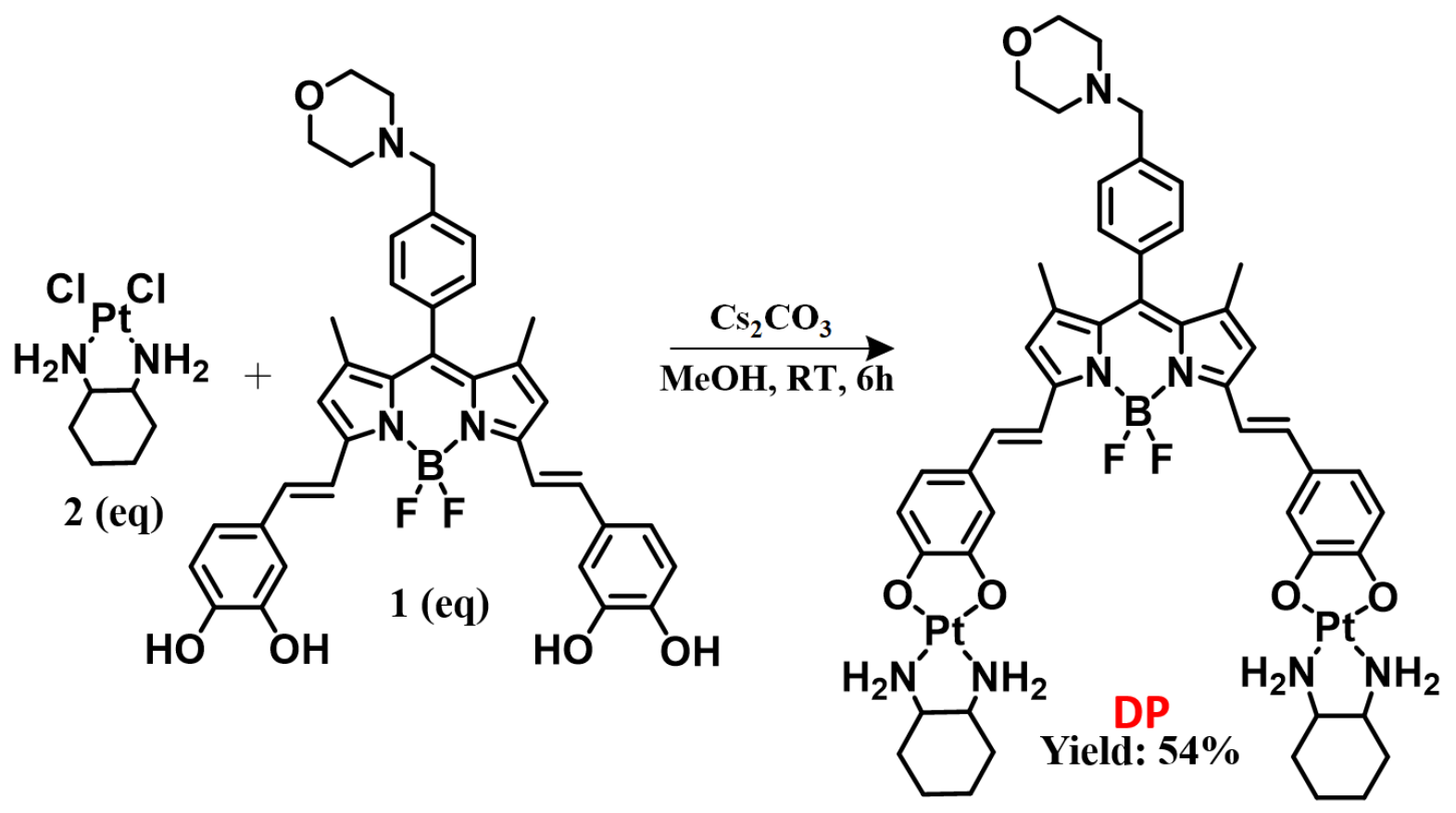

Scheme S2. Synthetic scheme of the complex DP. 


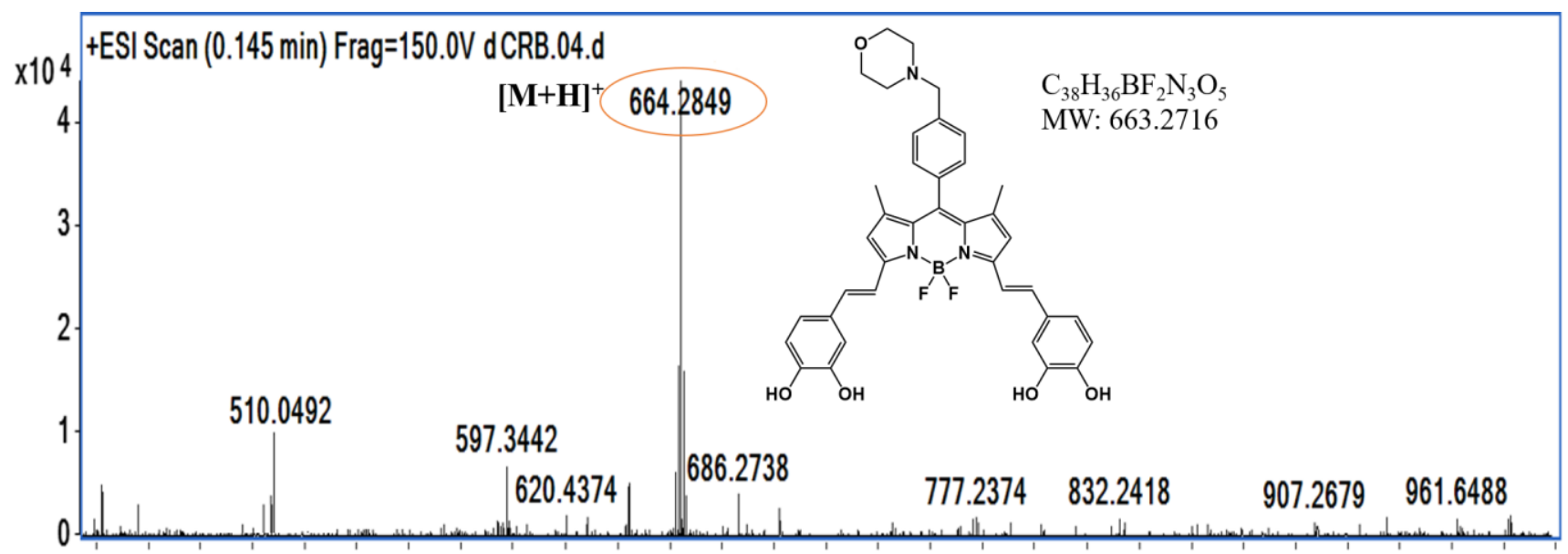

460480500520540560580600620640660680700720740760780800820840860880900920940960980

Counts vs. Mass-to-Charge (m/z)

Figure S1. Mass spectrum of ligand $\mathrm{H}_{4} \mathrm{Dcrb}$ in $\mathrm{MeOH}$ showing prominent parent ion peak at $664.2849(\mathrm{~m} / \mathrm{z})$ which corresponds to $[\mathrm{M}+\mathrm{H}]^{+}$.

(a)

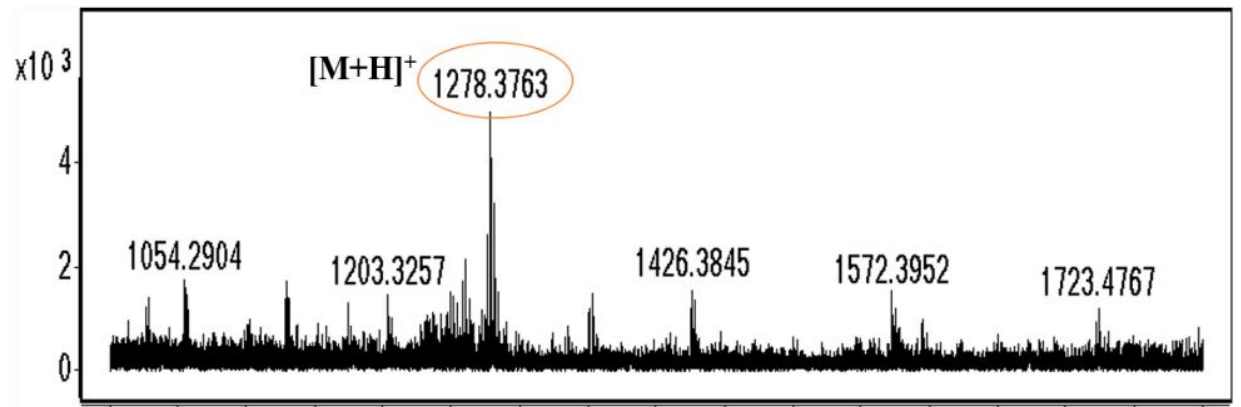

10001050110011501200125013001350140014501500155016001650170017501800 Counts vs. Mass-to-Charge(m/z)
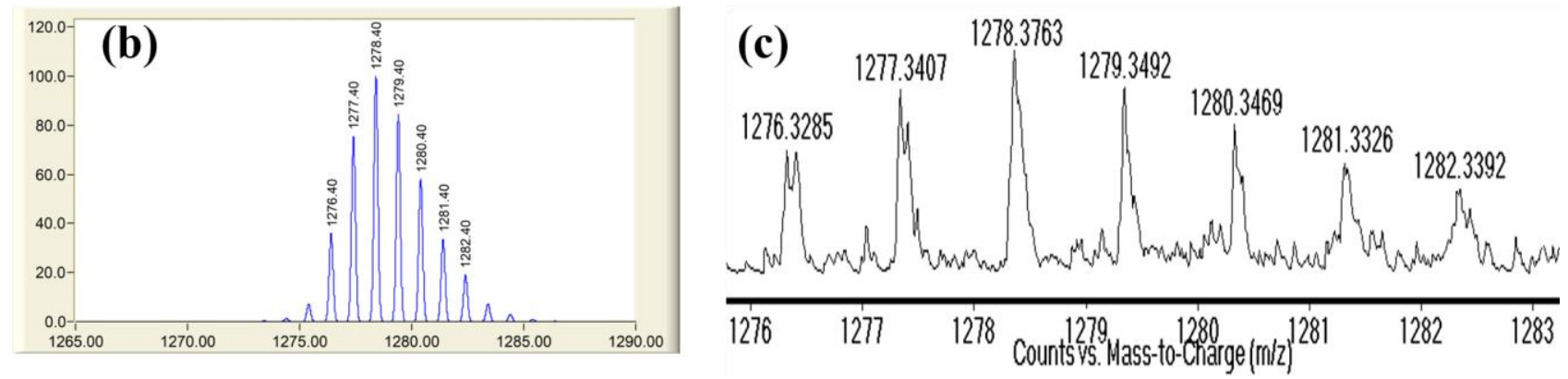

Figure S2. (a)Mass spectrum of complex DP in $\mathrm{MeOH}$ showing prominent parent ion peak at $1278.3763(\mathrm{~m} / \mathrm{z})$ which corresponds to $[\mathrm{M}+\mathrm{H}]^{+}$. (b) Calculated isotopic distribution pattern for DP. (c) The obtained isotopic distribution pattern for platinum of the molecular ion peak. 
(a)

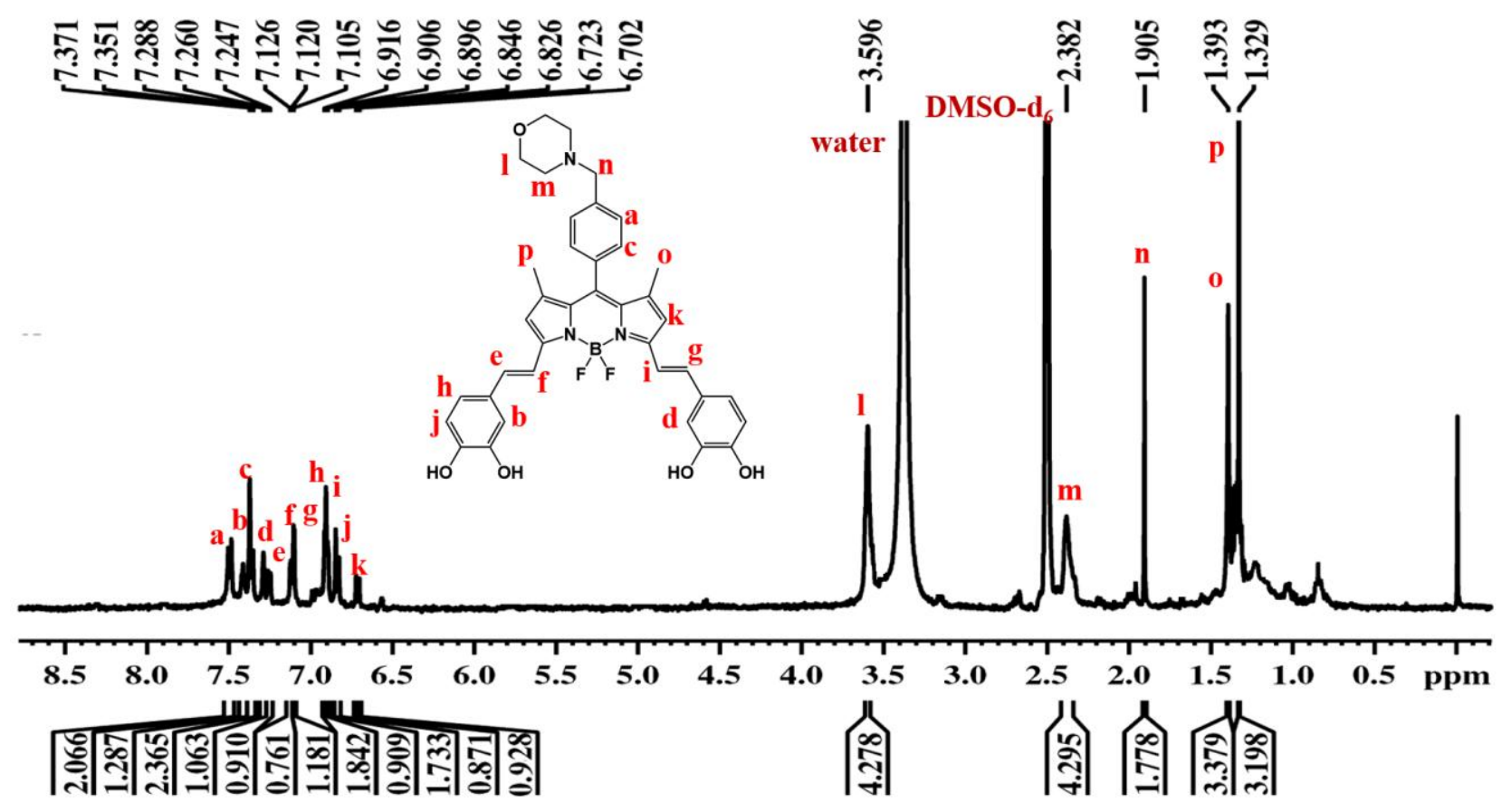

(b)

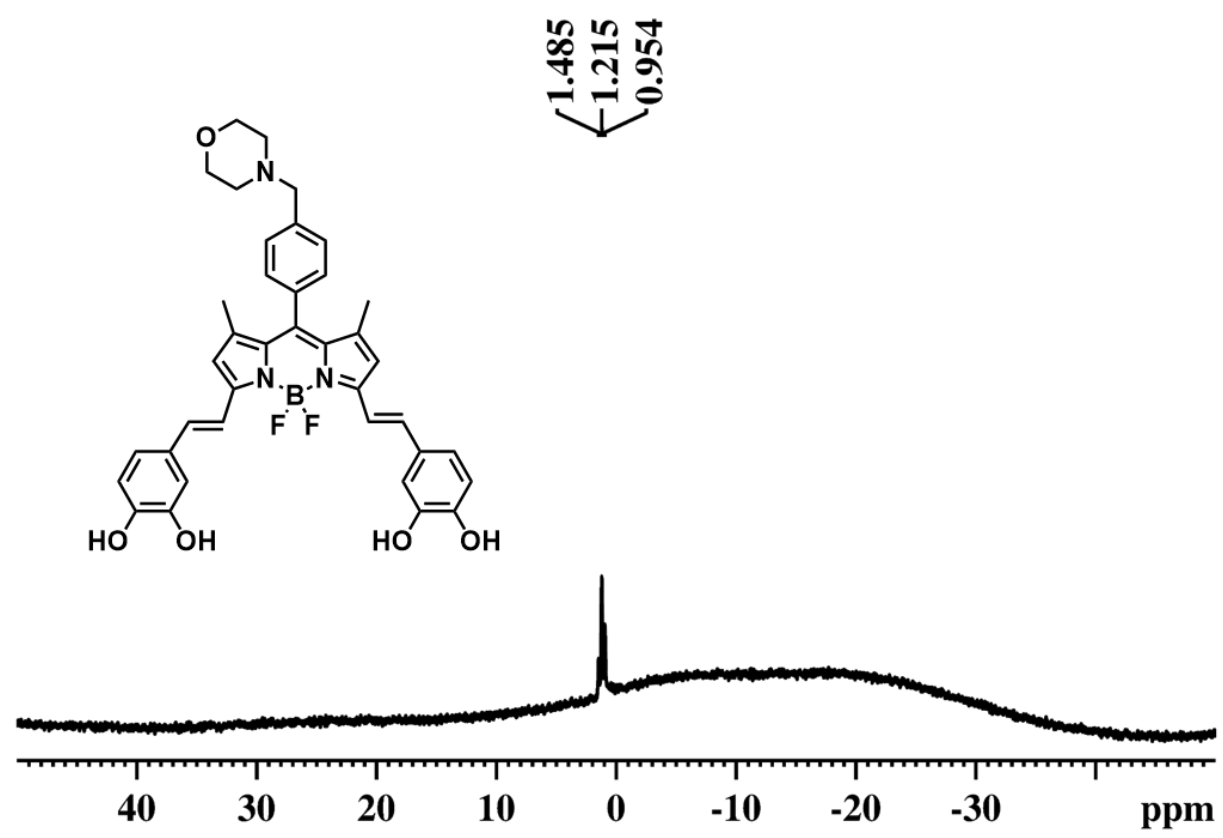

Figure S3. ${ }^{1} \mathrm{H}$ NMR (a) and ${ }^{11} \mathrm{~B}$ NMR (b) spectra of ligand $\mathrm{H}_{4}$ Dcrb in DMSO- $\mathrm{d}_{6}$. 


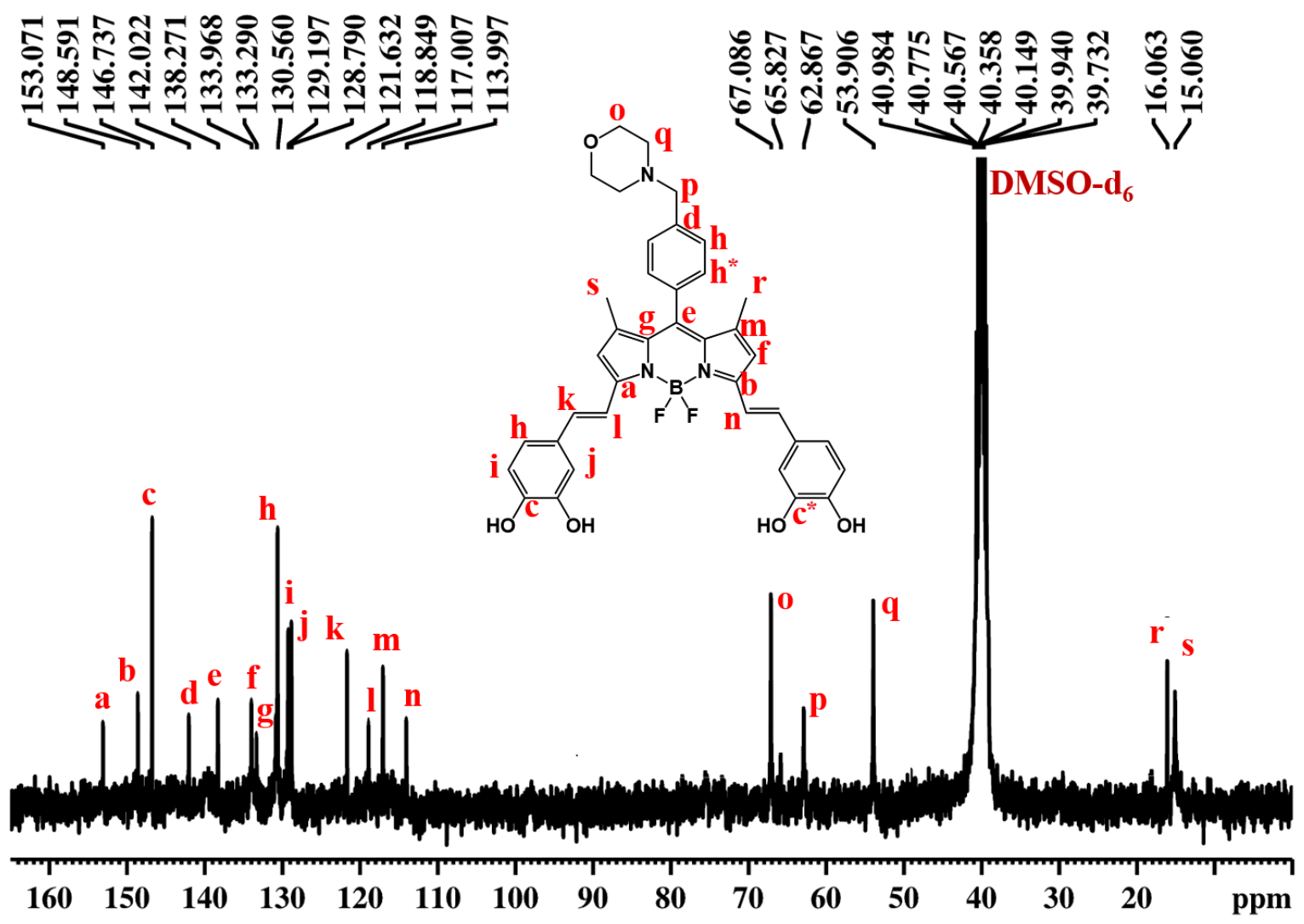

Figure S4. ${ }^{13} \mathrm{C}$ NMR spectrum of ligand $\mathrm{H}_{4} \mathrm{Dcrb}$ in DMSO- $\mathrm{d}_{6}$. 


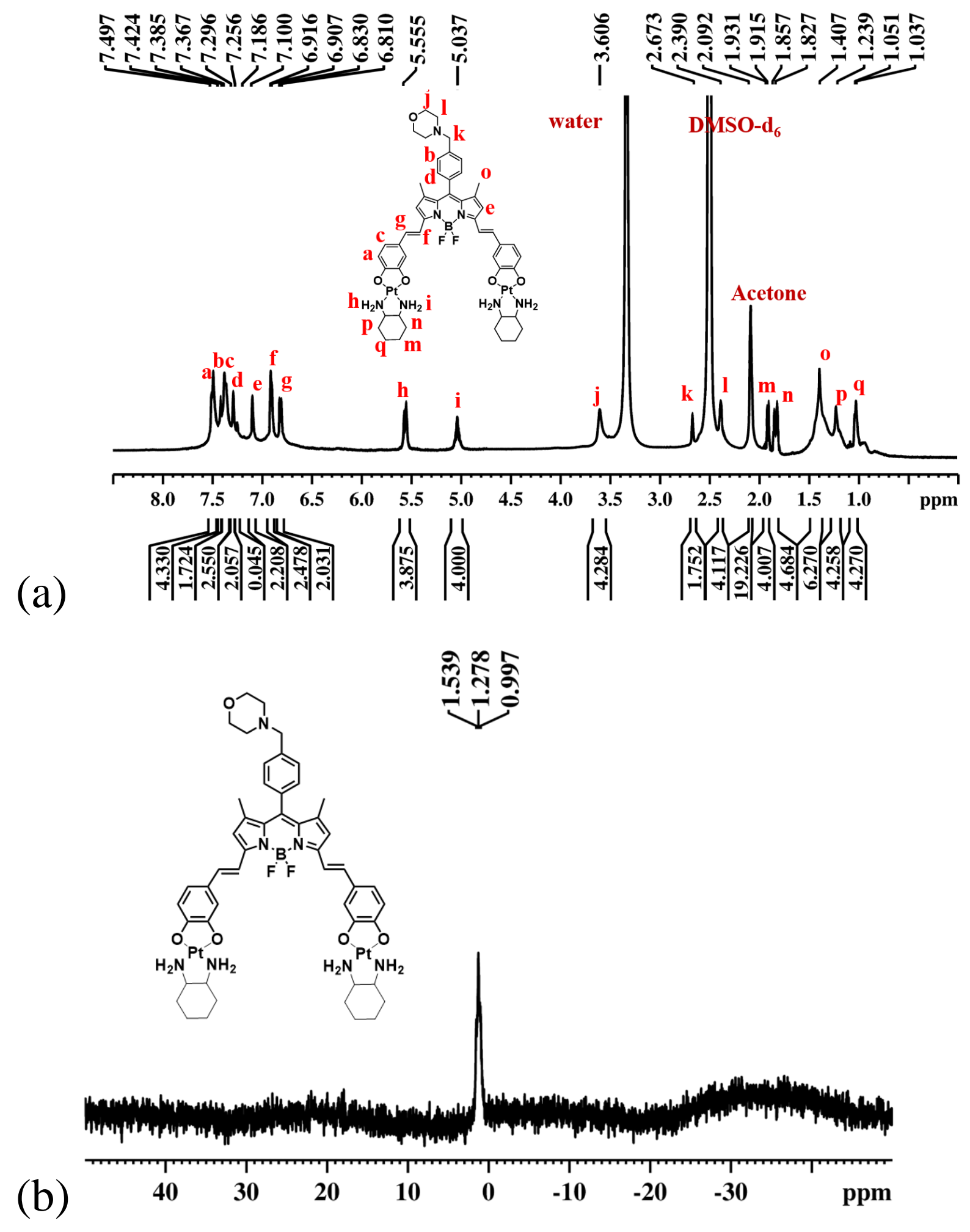

Figure S5: ${ }^{1} \mathrm{H}$ NMR (a) and ${ }^{11}$ B NMR (b) spectra of complex DP in DMSO- $\mathrm{d}_{6}$. 


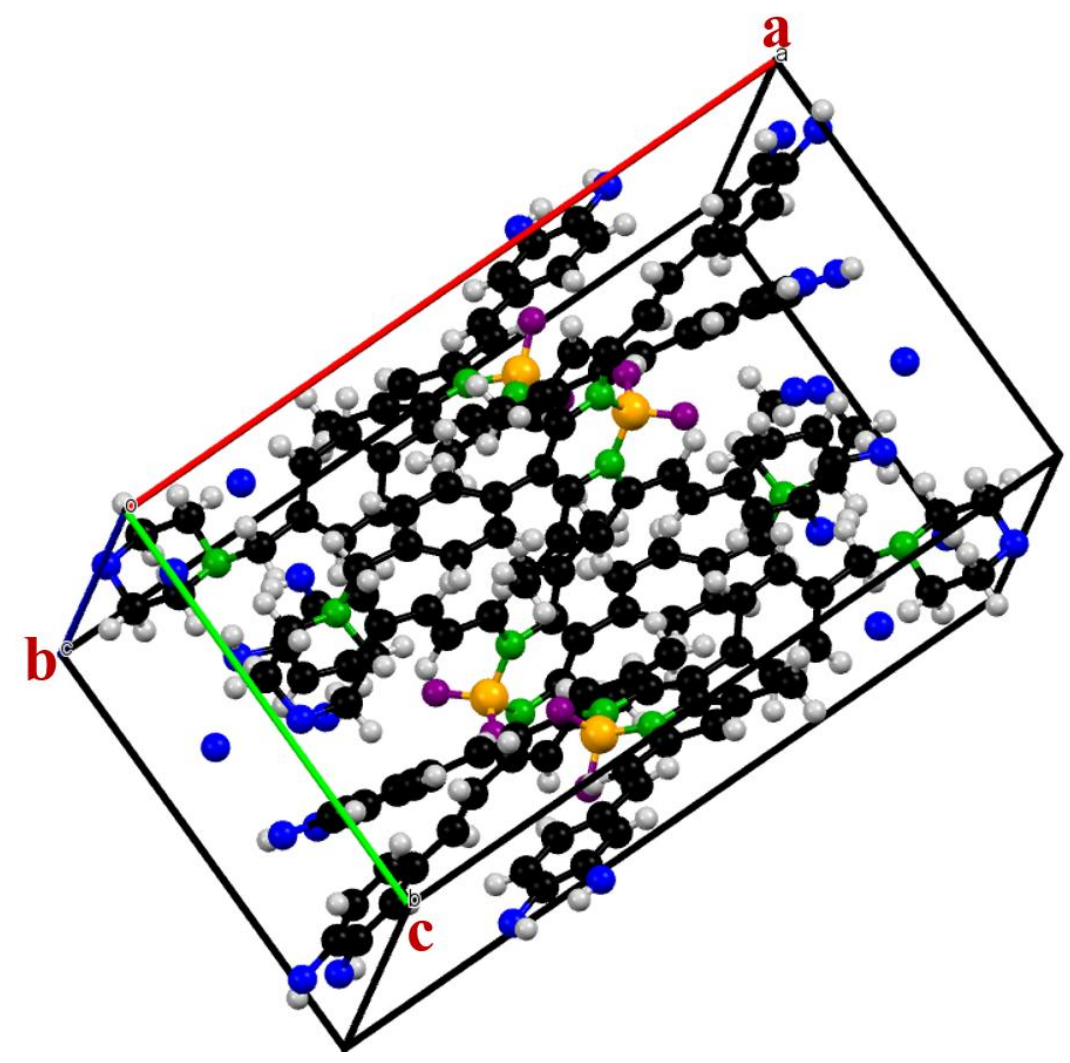

Figure S6: Unit cell packing diagram of the ligand $\mathrm{H}_{4} \mathrm{Dcrb}$ (color code: $\mathrm{B}$, orange; F, purple; $\mathrm{N}$, green; O, blue; C, black; H, grey). 


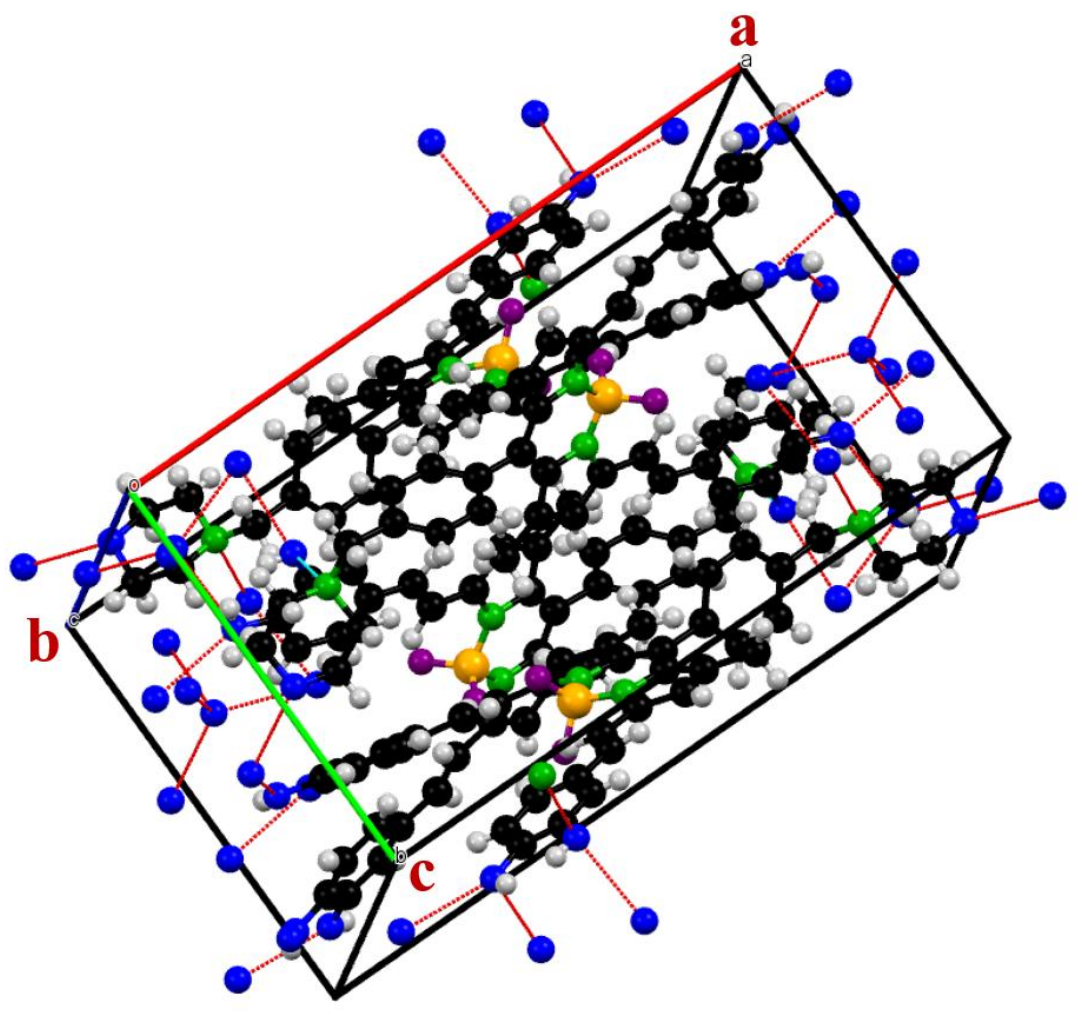

Figure S7. H-bonding involving the lattice water molecules and the ligand. 

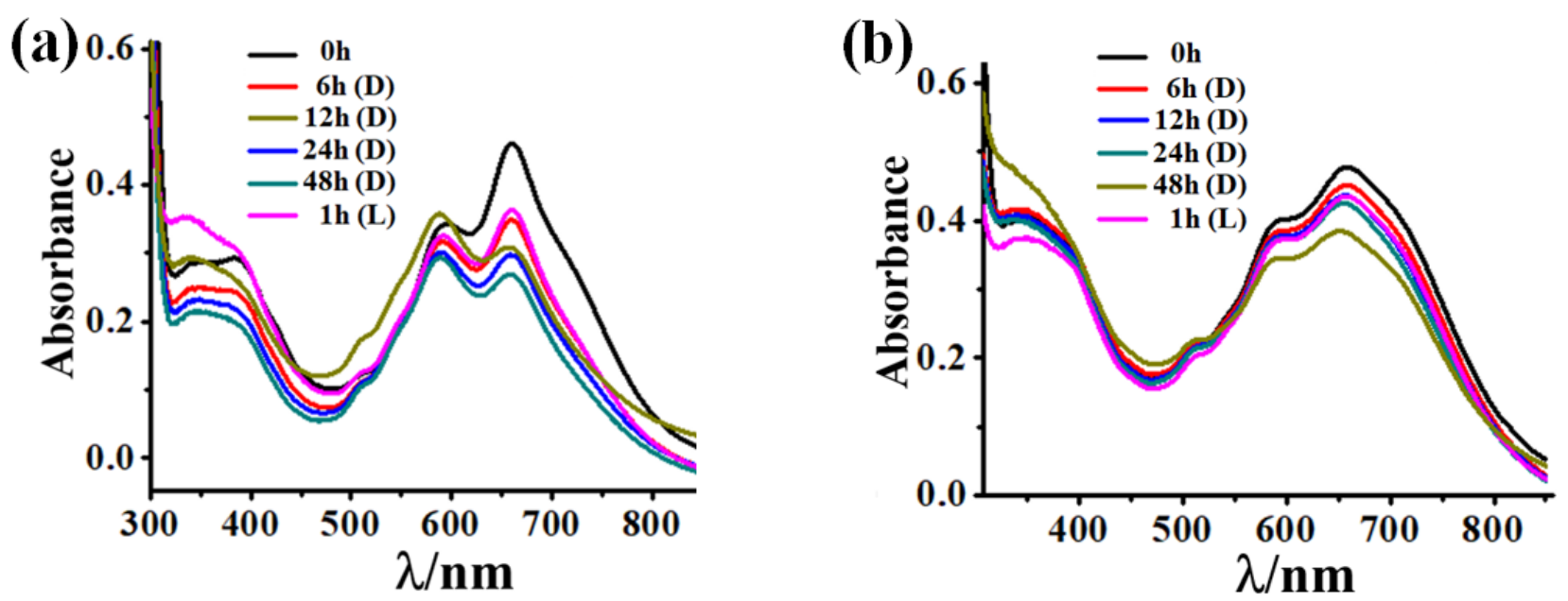

Figure S8. Time dependent UV-Vis spectra of the ligand $\mathrm{H}_{4} \mathrm{Dcrb}$ (a) and complex DP (b) in dark (D) and on visible light (400-700 $\mathrm{nm}$ ) exposure (L) in 10\% DMSO/DMEM solution.

(a)

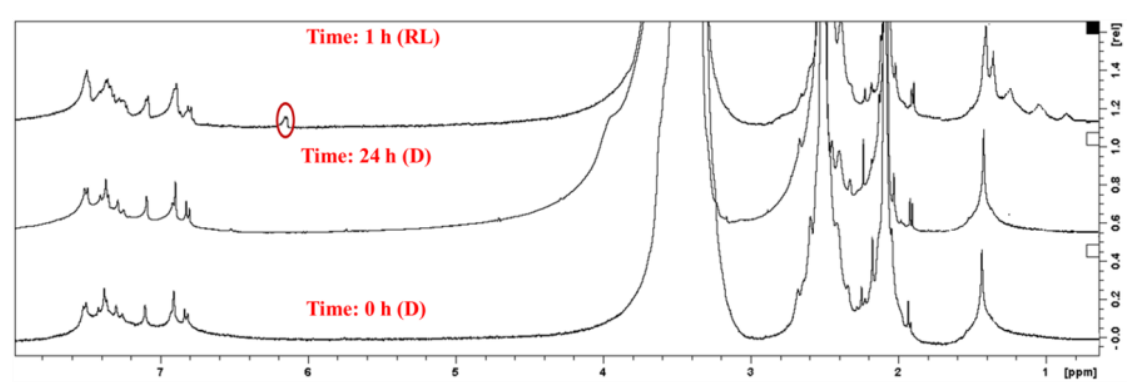

(b)

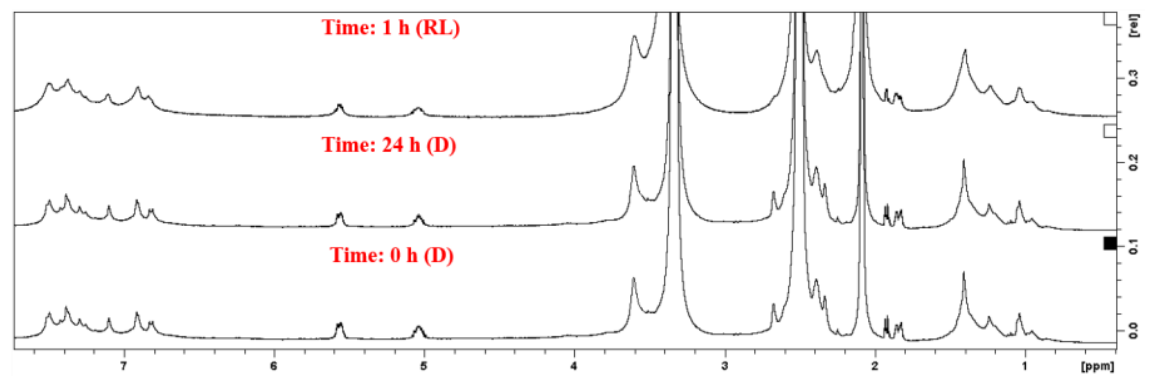

Figure S9. Time dependent ${ }^{1} \mathrm{H}$ NMR spectra of the ligand $\mathrm{H}_{4}$ Dcrb (a) and complex DP (b) in dark (D) and on red light $(600-720 \mathrm{~nm})$ exposure (RL) in DMSO- $\mathrm{d}_{6}$ solution. 

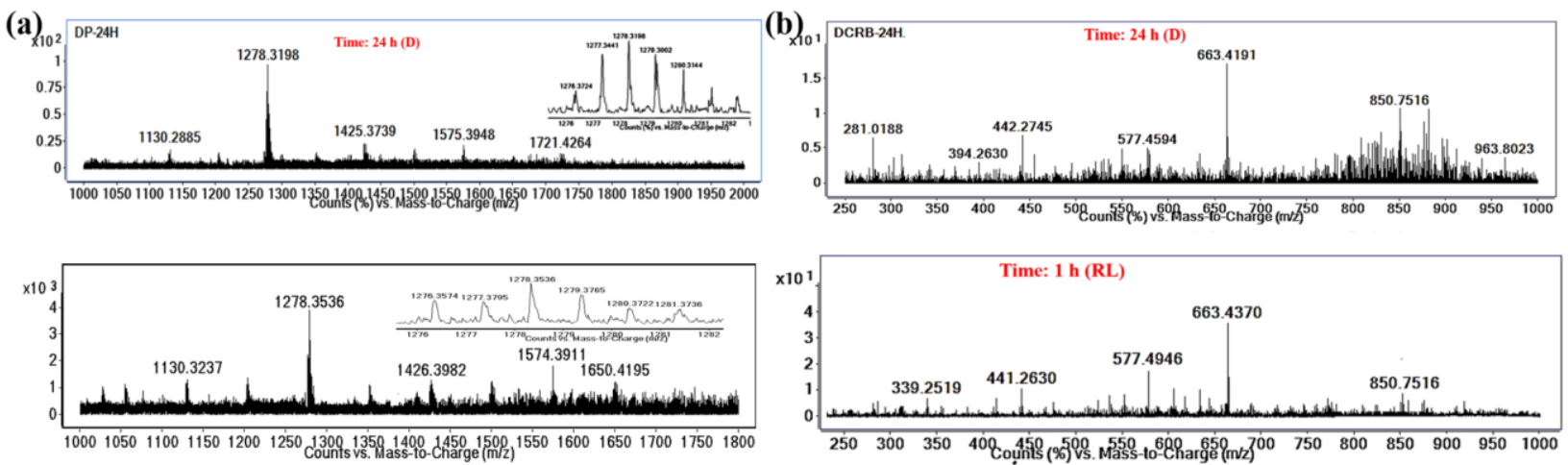

Figure S10. Time dependent ESI-mass of the complex DP (a) and ligand $\mathrm{H}_{4} \mathrm{Dcrb}$ (b) in dark (D) and on red light $(600-720 \mathrm{~nm})$ exposure $(\mathrm{RL})$ in $\mathrm{MeOH} / \mathrm{H}_{2} \mathrm{O}$ solution. Complex DP didn't show any change in the spectra however ligand $\mathrm{H}_{4}$ Dcrb gave $[\mathrm{M}]^{+}$.peak. 


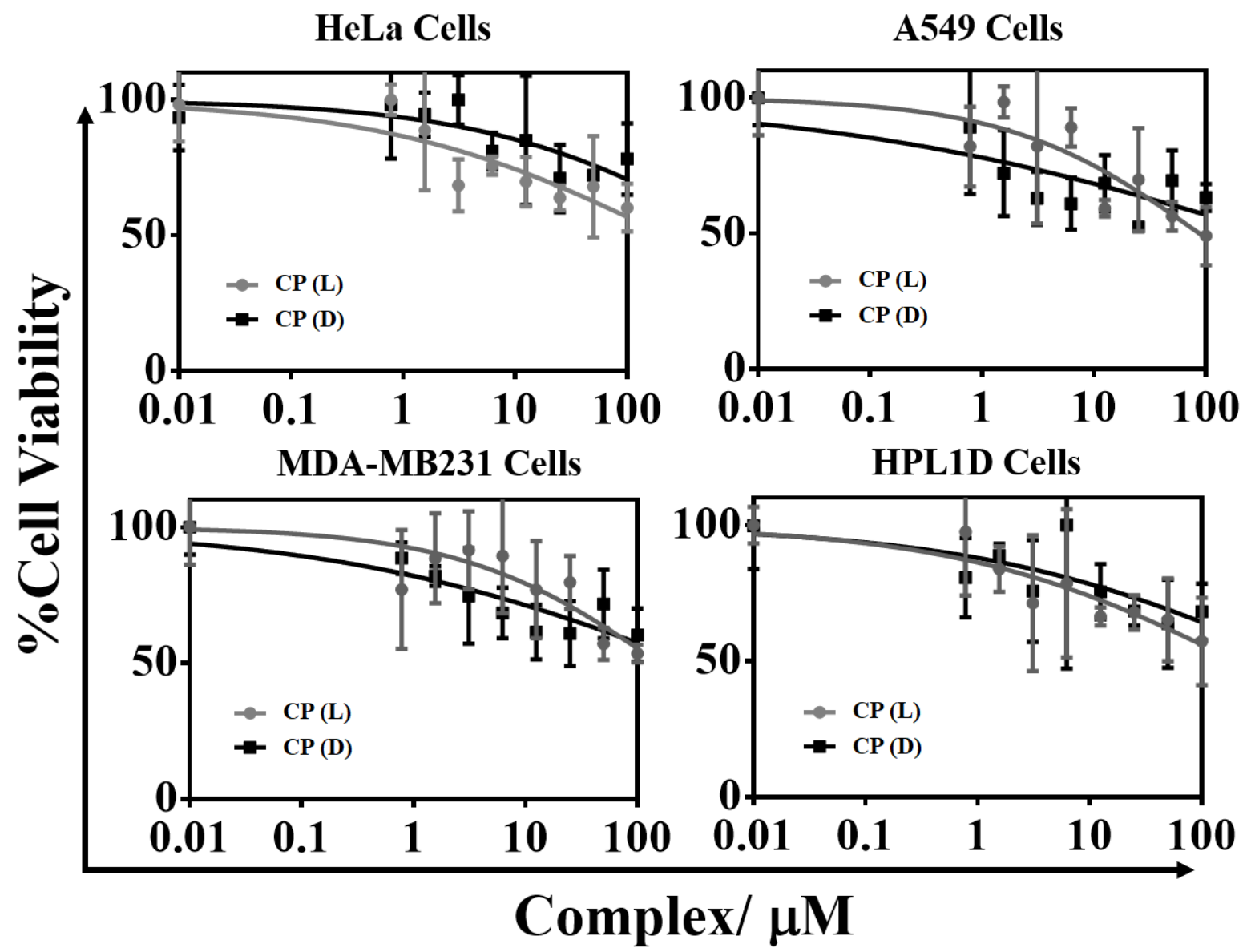

Figure S11. Cell viability plots as obtained from the MTT assay in HeLa, A549, MDA-MB231 and HPL1D cells treated with complex CP for $4 \mathrm{~h}$ initial incubation period in dark. Cells were exposed to red light $\left(\lambda=600-720 \mathrm{~nm}\right.$, light dose $\left.=30 \mathrm{~J} \mathrm{~cm}^{-2}\right)$ (black symbols for dark; grey symbols for red light). 


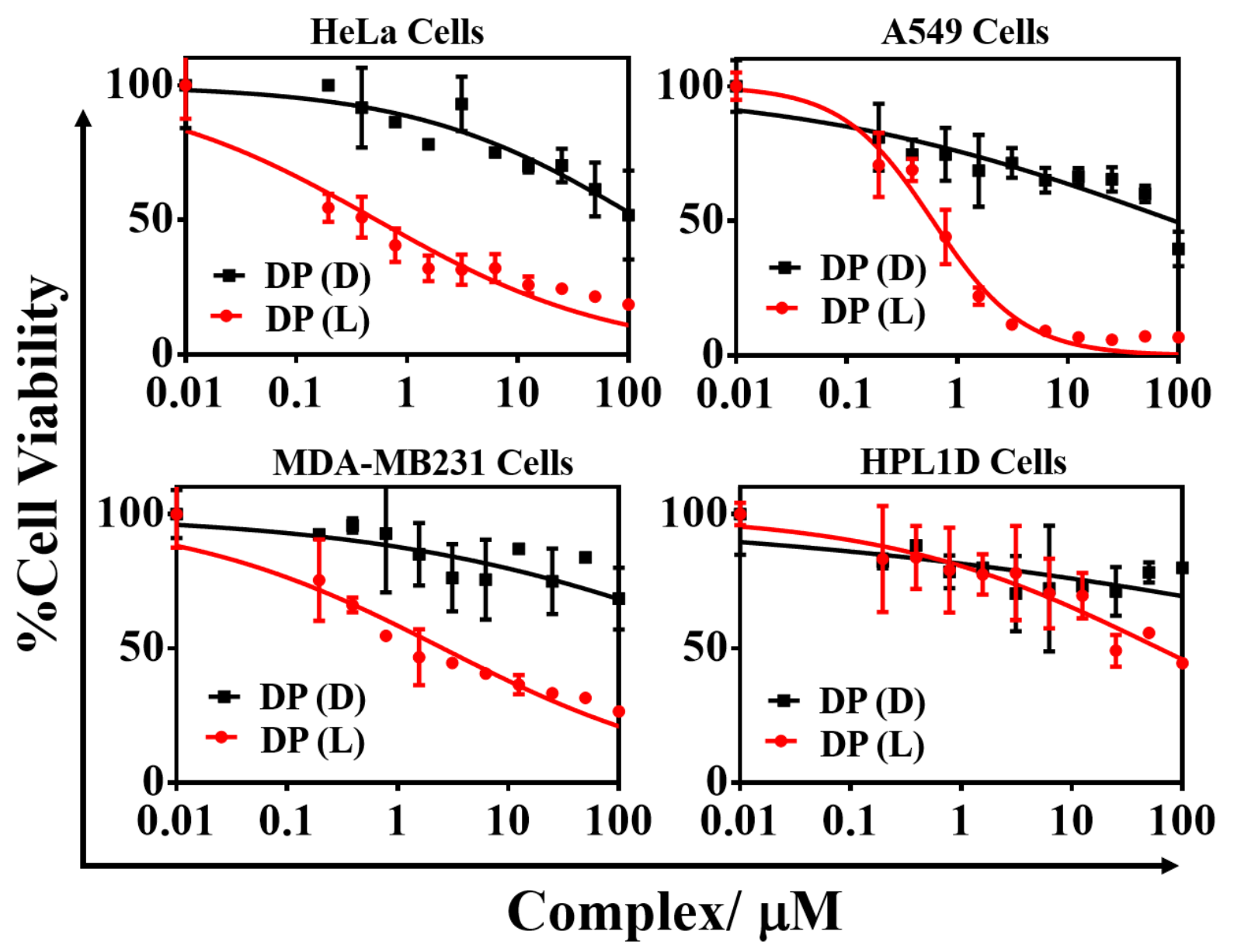

Figure S12. Cell viability plots as obtained from the MTT assay in HeLa, A549, MDA-MB231 and HPL1D cells treated with complex DP for $4 \mathrm{~h}$ initial incubation period in dark. Cells were exposed to red light $\left(\lambda=600-720 \mathrm{~nm}\right.$, light dose $\left.=30 \mathrm{~J} \mathrm{~cm}^{-2}\right)$ (black symbols for dark; red symbols for red light). 


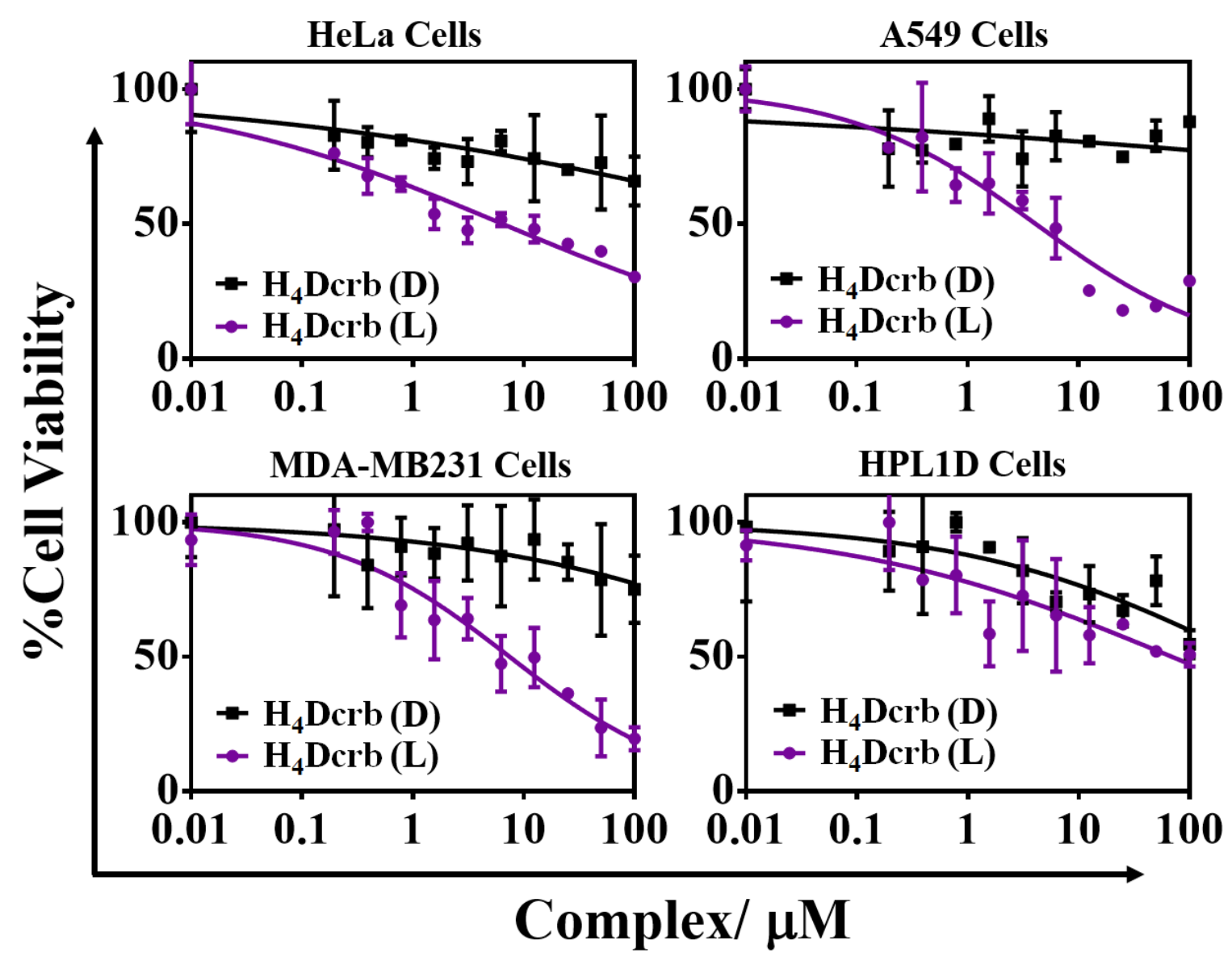

Figure S13. Cell viability plots as obtained from the MTT assay in HeLa, A549, MDA-MB231 and HPL1D cells treated with $\mathrm{H}_{4}$ Dcrb for $4 \mathrm{~h}$ initial incubation period in dark. Cells were exposed to red light $\left(\lambda=600-720 \mathrm{~nm}\right.$, light dose $\left.=30 \mathrm{~J} \mathrm{~cm}^{-2}\right)$ (black symbols in the dark; purple symbols in red light). 


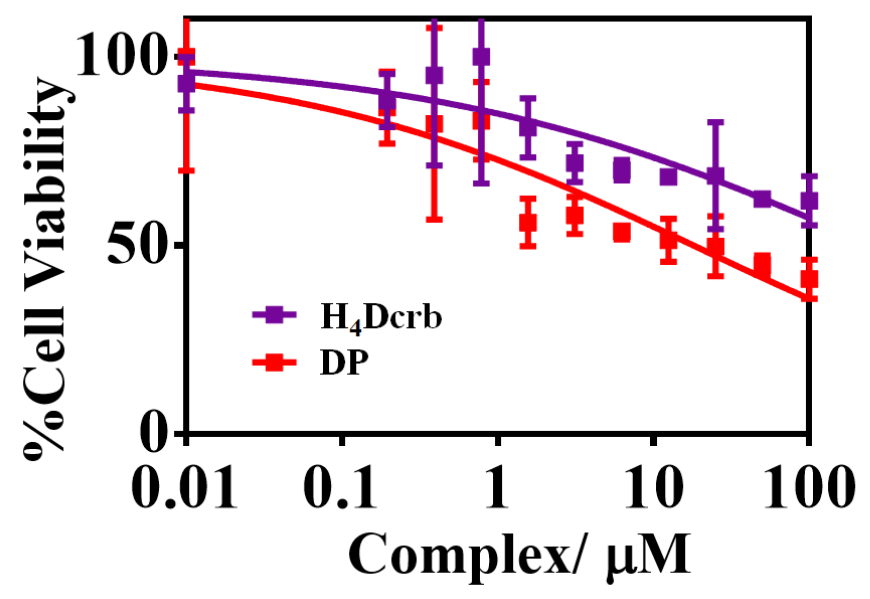

Figure S14. Cell viability plots as obtained from the MTT assay in A549 cells treated with complex DP and ligand $\mathrm{H}_{4} \mathrm{Dcrb}$ for $24 \mathrm{~h}$ incubation period in dark. 

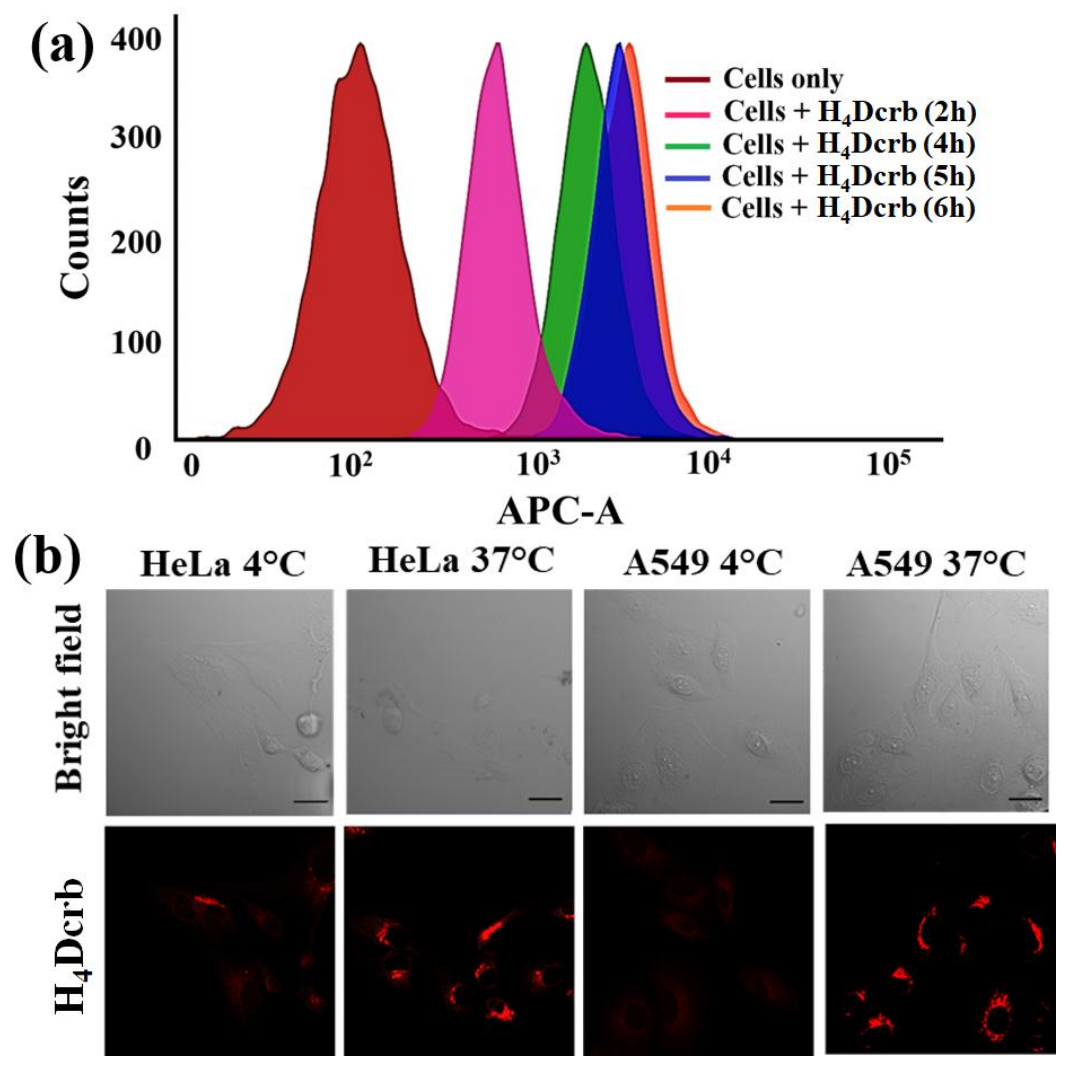

Figure S15. (a) Quantitative analysis of cellular uptake of the compounds by flow cytometry upon incubating A549 cells with $\mathrm{H}_{4} \mathrm{Dcrb}(1 \mu \mathrm{M})$ at $37{ }^{\circ} \mathrm{C}$ at different time intervals with cells untreated used as a control. (b) Confocal images of HeLa and A549 cells incubated with $\mathrm{H}_{4} \mathrm{Dcrb}(5 \mu \mathrm{M})$ at two different temperatures $37{ }^{\circ} \mathrm{C}$ and $4{ }^{\circ} \mathrm{C}$ for $4 \mathrm{~h}$. Scale bar: $20 \mu \mathrm{m}$. 


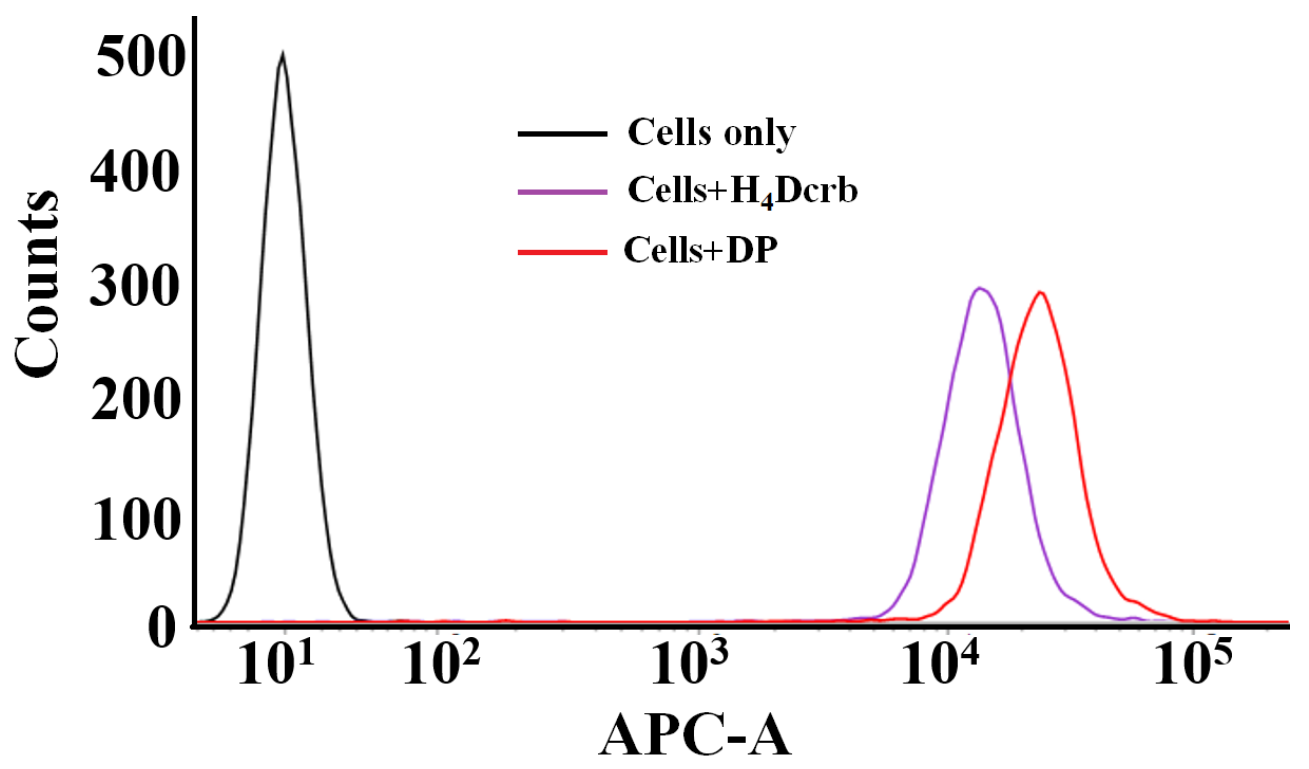

Figure S16. Quantitative analysis of cellular uptake of the compounds by flow cytometry upon incubating HPL1D cells with DP and $\mathrm{H}_{4} \mathrm{Dcrb}(1 \mu \mathrm{M})$ at $37^{\circ} \mathrm{C}$ for $4 \mathrm{~h}$.

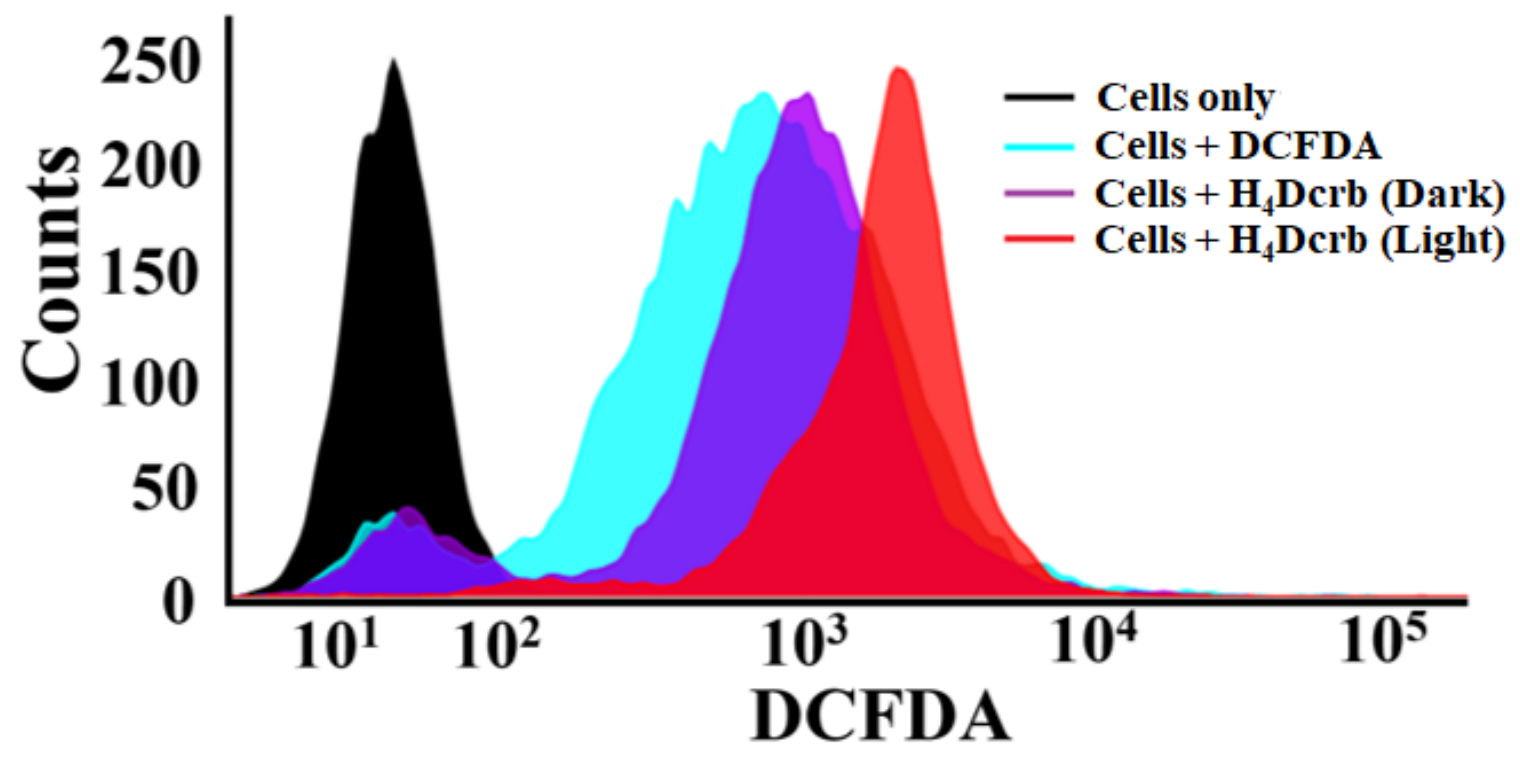

Figure S17. The generation of cellular ROS in A549 cells by DCFDA assay with $\mathrm{H}_{4} \mathrm{Dcrb}(5 \mu \mathrm{M}, 4 \mathrm{~h})$ treatment under red light irradiation $\left(\lambda=600-720 \mathrm{~nm}\right.$, light dose $\left.=30 \mathrm{~J} \mathrm{~cm}^{-2}\right)$ and dark. 

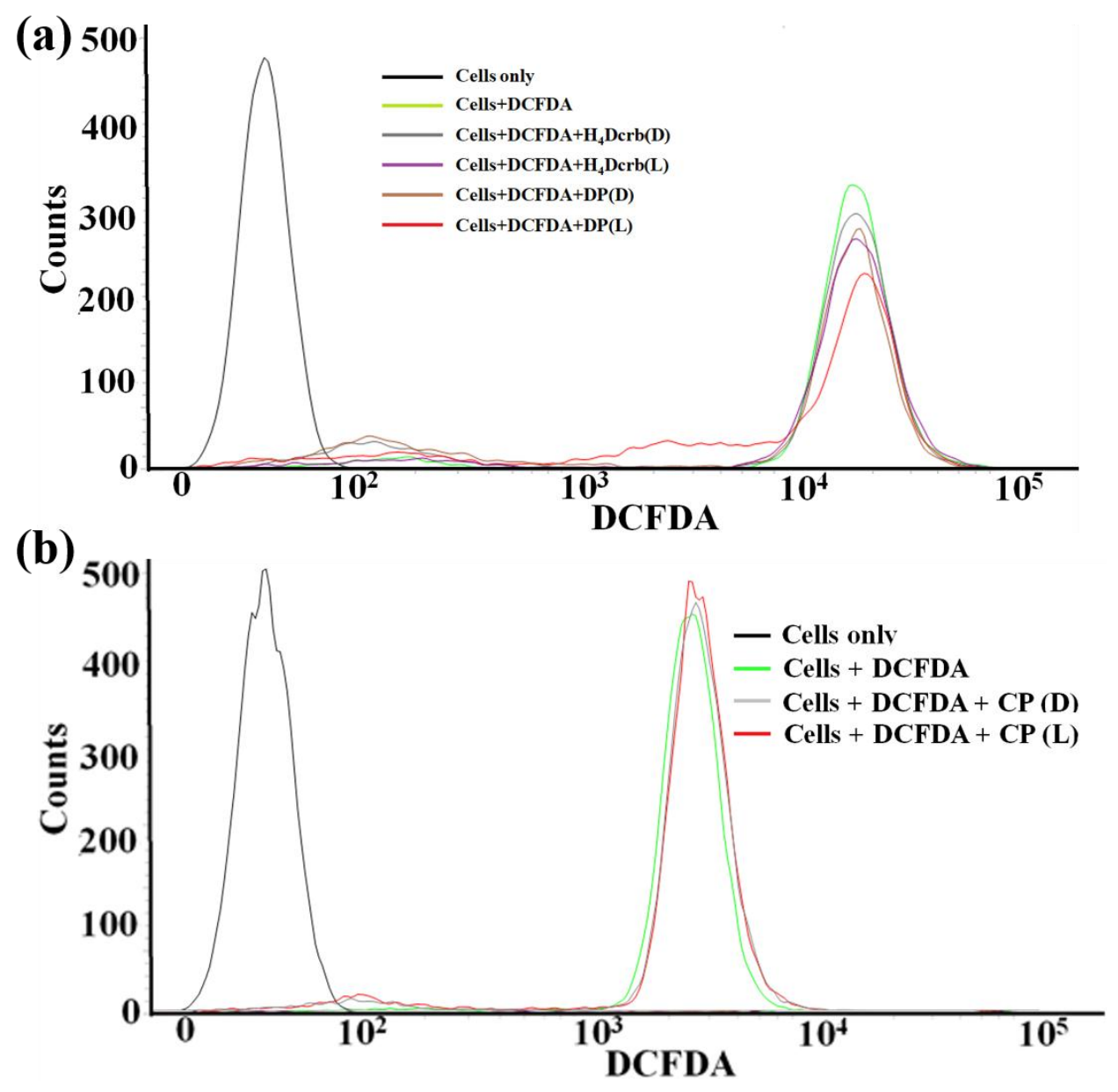

Figure S18. (a) The generation of cellular ROS in HPL1D cells by DCFDA assay with $\mathrm{H}_{4} \mathrm{Dcrb}(5 \mu \mathrm{M}$, $4 \mathrm{~h})$ and DP $(0.5 \mu \mathrm{M})$ treatment under red light irradiation $\left(\lambda=600-720 \mathrm{~nm}\right.$, light dose $\left.=30 \mathrm{~J} \mathrm{~cm}^{-2}\right)$ and dark. (b) The generation of cellular ROS in A549 cells by DCFDA assay with CP (100 $\mu \mathrm{M}, 4 \mathrm{~h})$ treatment under red light irradiation $\left(\lambda=600-720 \mathrm{~nm}\right.$, light dose $\left.=30 \mathrm{~J} \mathrm{~cm}^{-2}\right)$ and dark. 


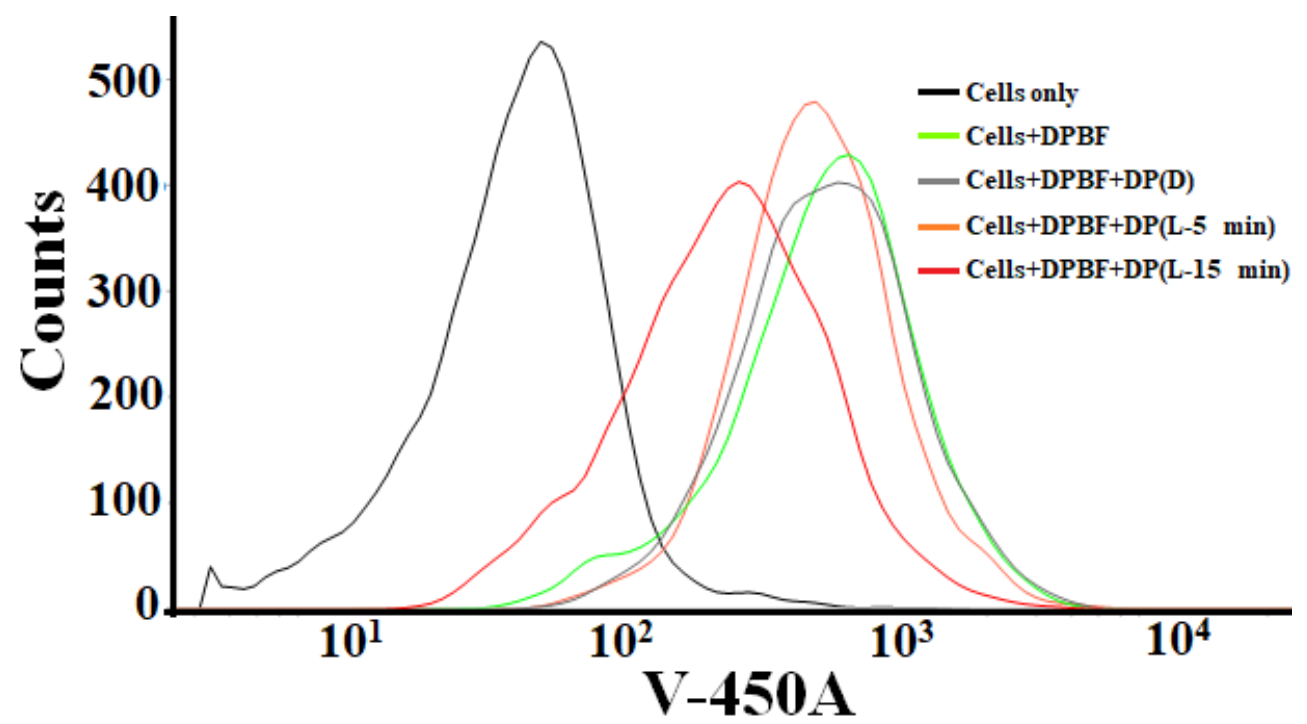

Figure S19. The generation of singlet oxygen in A549 cells by DPBF assay with DP $(0.5 \mu \mathrm{M}, 4 \mathrm{~h})$ treatment under red light irradiation $\left(\lambda=600-720 \mathrm{~nm}\right.$, light dose $\left.=30 \mathrm{~J} \mathrm{~cm}^{-2}\right)$ and dark.

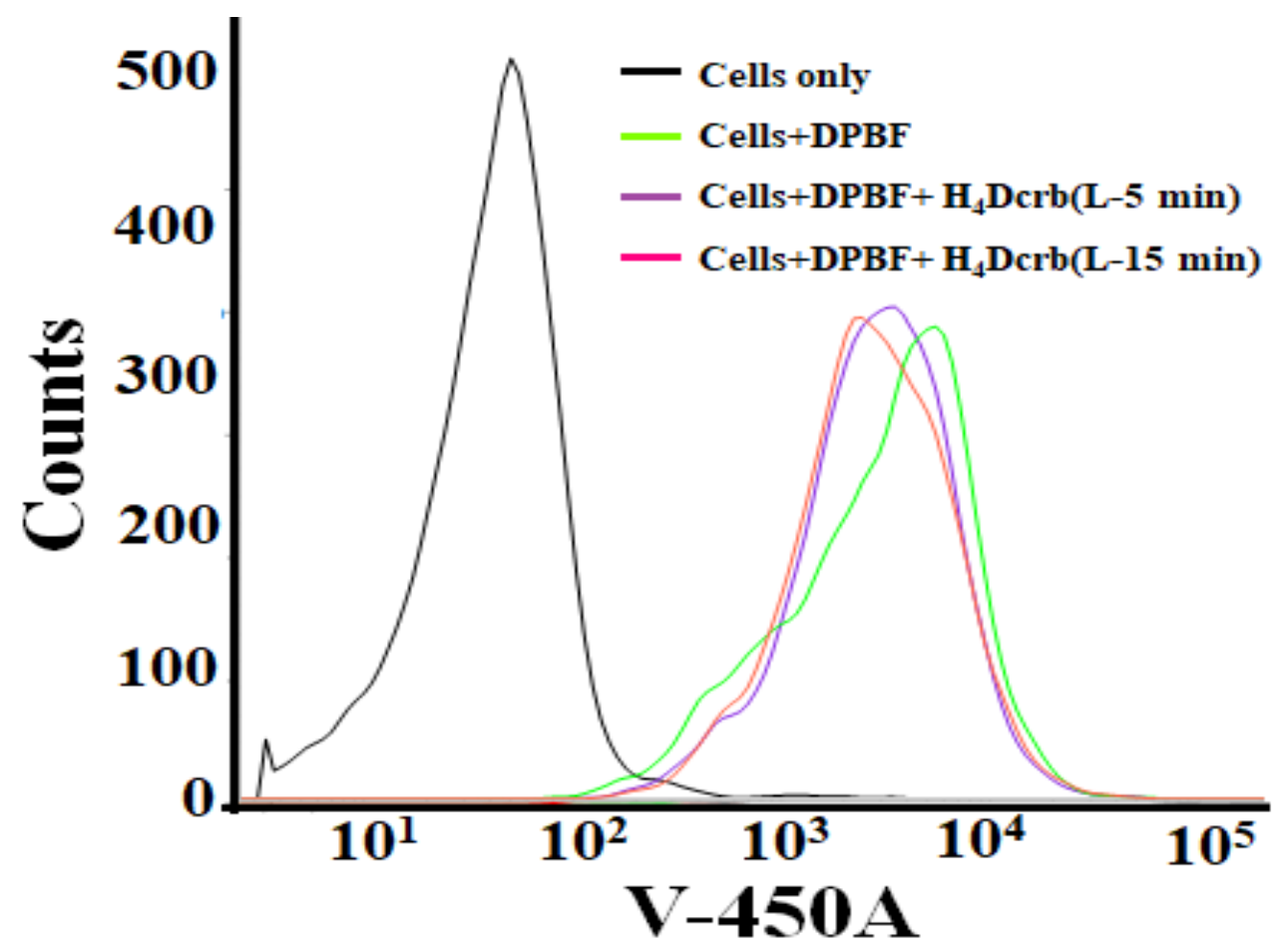

Figure S20. The generation of singlet oxygen in A549 cells by DPBF assay with $\mathrm{H}_{4} \mathrm{Dcrb}(5 \mu \mathrm{M}, 4 \mathrm{~h})$ treatment under red light irradiation $\left(\lambda=600-720 \mathrm{~nm}\right.$, light dose $\left.=30 \mathrm{~J} \mathrm{~cm}^{-2}\right)$ and dark. 


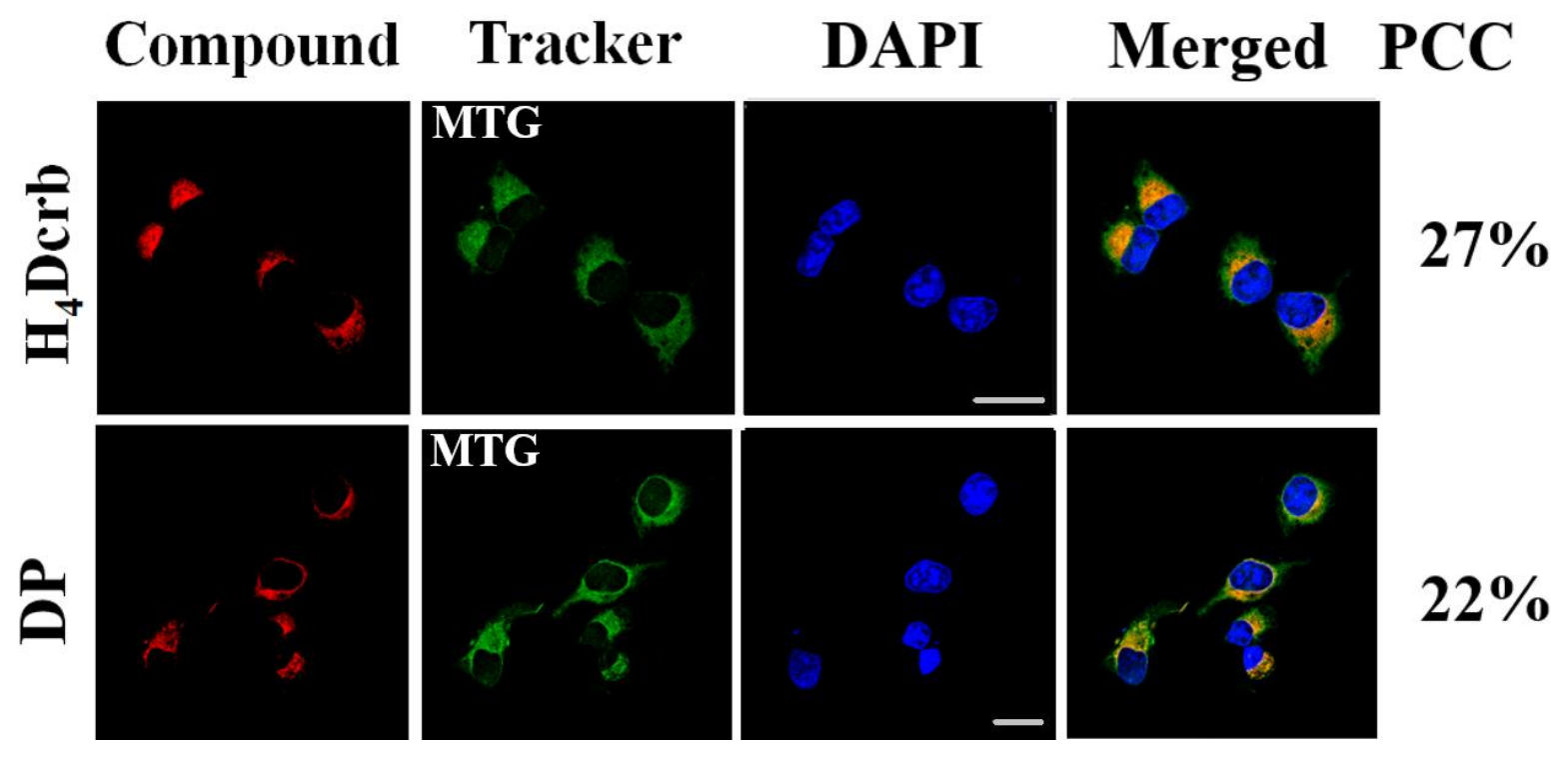

Figure S21. Confocal images of A549 cells incubated with DP and the ligand $(5 \mu \mathrm{M})$ for $4 \mathrm{~h}$ followed by $15 \mathrm{~min}$ incubation at different $\mathrm{pH}$ at $37^{\circ} \mathrm{C}$ in dark. Scale bar is $20 \mu \mathrm{m}$. MTG is mito tracker green. DAPI is 4',6-diamidino-2-phenylindole. 


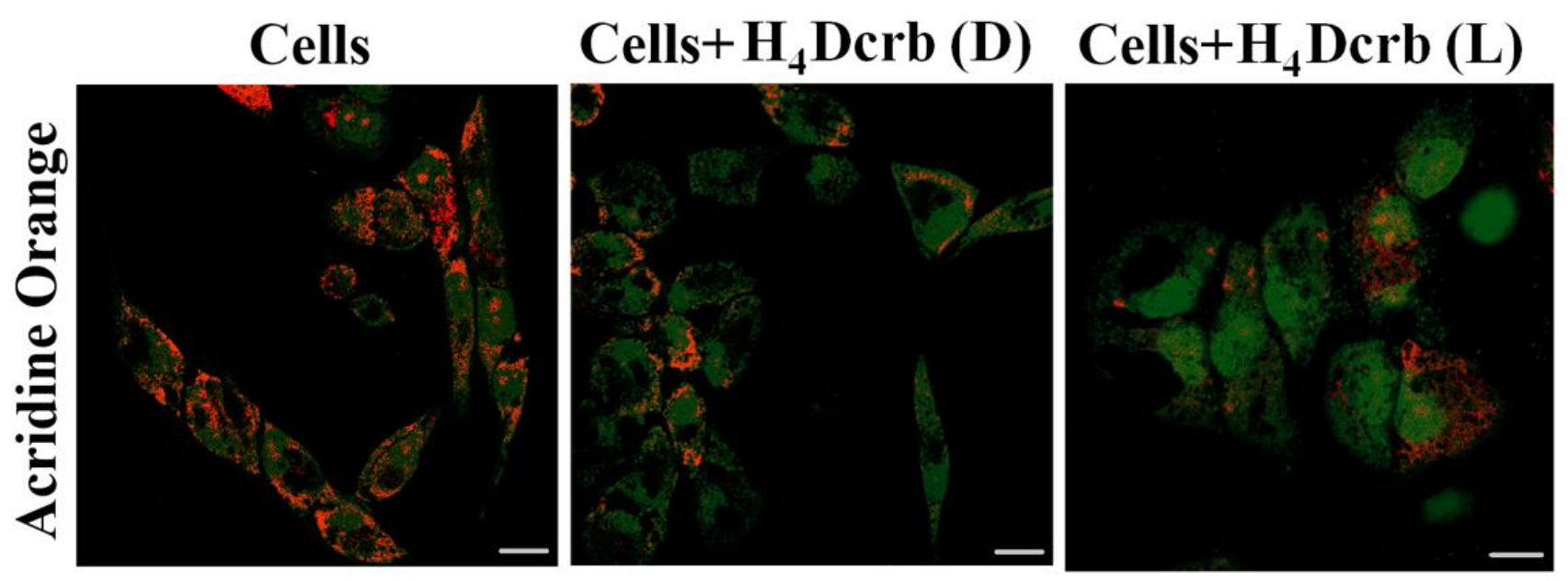

Figure S22. (a) Acridine orange staining of A549 cells to detect disruption of lysosome membrane with treatment of $\mathrm{H}_{4}$ Dcrb $(5 \mu \mathrm{M})$, kept in dark for $4 \mathrm{~h}$ followed by irradiation under red light $(\lambda=$ $600-720 \mathrm{~nm}$, light dose $=30 \mathrm{~J} \mathrm{~cm}^{-2}$ ) for (L) and without irradiation (D). 
Table S1. Selected Crystallographic Parameters for the Ligand $\mathrm{H}_{4}$ Dcrb

\begin{tabular}{|c|c|}
\hline & $\mathrm{H}_{4}$ Dcrb. $2 \mathrm{H}_{2} \mathrm{O}$ \\
\hline Empirical formula & $\mathrm{C}_{38} \mathrm{H}_{36} \mathrm{~B} \mathrm{~F}_{2} \mathrm{~N}_{3} \mathrm{O}_{5} .2 \mathrm{H}_{2} \mathrm{O}$ \\
\hline Fw/g M ${ }^{-1}$ & 699.55 \\
\hline Crystal system & Monoclinic \\
\hline Space group & $P 2{ }_{1} / c$ \\
\hline$a / \AA$ & $20.3901(2)$ \\
\hline$b / \AA$ & $12.6056(2)$ \\
\hline$c / \AA$ & $13.9288(5)$ \\
\hline$\alpha / \operatorname{deg}$ & 90.00 \\
\hline$\beta / \mathrm{deg}$ & $98.62(2)$ \\
\hline$\gamma / \operatorname{deg}$ & 90.00 \\
\hline$V / \AA^{3}$ & $3539.6(2)$ \\
\hline$Z$ & 4 \\
\hline$T, \mathrm{~K}$ & 298 \\
\hline$\rho_{\text {calcd }} / \mathrm{Mg} \mathrm{m}^{-3}$ & 1.305 \\
\hline$\lambda / \AA(\mathrm{Mo}-\mathrm{K} \alpha)$ & 0.71073 \\
\hline Data/restraints/param. & $2823 / 0 / 466$ \\
\hline$F(000)$ & 1456.0 \\
\hline GOF & 1.299 \\
\hline$R\left(F_{\mathrm{o}}\right),{ }^{\mathrm{a}} I>2 \sigma(I)\left[w R\left(F_{\mathrm{o}}\right)^{\mathrm{b}}\right]$ & $0.097[0.288]$ \\
\hline$R$ (all data) $[w R$ (all data) $]$ & $0.075[0.252]$ \\
\hline Highest diff peak, hole $\left(\mathrm{e} \AA^{-3}\right)$ & $0.9391,-0.4015$ \\
\hline \multirow[t]{2}{*}{$w=1 /\left[\left(\sigma F_{\mathrm{o}}\right)^{2}+(\mathrm{AP})^{2}+(\mathrm{BP})\right]$} & $\mathrm{A}=0.20$ \\
\hline & $\mathrm{B}=1.8637$ \\
\hline \multicolumn{2}{|c|}{$\begin{array}{l}{ }^{\mathrm{a}} \mathrm{R}=\Sigma\left|\mathrm{F}_{\mathrm{o}}\right|-\left|\mathrm{F}_{\mathrm{c}}\right| / \Sigma\left|\mathrm{F}_{\mathrm{o}}\right| \cdot{ }^{\mathrm{b}} \mathrm{wR}=\left\{\Sigma\left[\mathrm{w}\left(\mathrm{F}_{\mathrm{o}}{ }^{2}-\mathrm{F}_{\mathrm{c}}{ }^{2}\right)^{2}\right] / \Sigma\left[\mathrm{w}\left(\mathrm{F}_{\mathrm{o}}\right)^{2}\right]\right\}^{1 / 2} \text {; where } \mathrm{P} \\
=\left(\mathrm{F}_{\mathrm{o}}{ }^{2}+2 \mathrm{~F}_{\mathrm{c}}{ }^{2}\right) / 3\end{array}$} \\
\hline
\end{tabular}


Table S2. Selected Bond Distances $(\AA)$ and Angles $\left({ }^{\circ}\right)$ for the Ligand $\mathrm{H}_{4}$ Dcrb.2 $\mathrm{H}_{2} \mathrm{O}$ with Estimated Standard Deviations in the Parentheses

$\begin{array}{cc}\mathrm{B}(1)-\mathrm{F}(1) & 1.407(2) \\ \mathrm{B}(1)-\mathrm{F}(2) & 1.378(4) \\ \mathrm{B}(1)-\mathrm{N}(2) & 1.525(4) \\ \mathrm{B}(1)-\mathrm{N}(3) & 1.534(4) \\ \mathrm{N}(2)-\mathrm{C}(17) & 1.361(4) \\ \mathrm{N}(2)-\mathrm{C}(14) & 1.395(4) \\ \mathrm{N}(3)-\mathrm{C}(22) & 1.371(4) \\ \mathrm{N}(3)-\mathrm{C}(13) & 1.386(4) \\ \mathrm{F}(2)-\mathrm{B}(1)-\mathrm{F}(1) & 108.25(1) \\ \mathrm{F}(2)-\mathrm{B}(1)-\mathrm{N}(2) & 111.16(3) \\ \mathrm{F}(1)-\mathrm{B}(1)-\mathrm{N}(3) & 109.74(3) \\ \mathrm{F}(2)-\mathrm{B}(1)-\mathrm{N}(3) & 111.59(3) \\ \mathrm{F}(1)-\mathrm{B}(1)-\mathrm{N}(2) & 109.65(3) \\ \mathrm{N}(2)-\mathrm{B}(1)-\mathrm{N}(3) & 106.43(3)\end{array}$


Table S3. Coordinates for Optimized Geometry of Complex DP obtained from DFT Calculations using B3LYP/LANL2DZ Level of Theory for All Atoms.

\section{Complex DP}

$\begin{array}{llll}6 & 1.162468275 & 11.514395067 & -0.531379283\end{array}$

$\begin{array}{llll}6 & 0.988721794 & 9.317506880 & 0.757147919\end{array}$

$\begin{array}{llll}6 & 0.905450579 & 9.243290088 & -1.664480728\end{array}$

$\begin{array}{llll}6 & 0.816949938 & 7.923783073 & 0.804650489\end{array}$

$\begin{array}{llll}1 & 1.103359896 & 9.891486497 & 1.672971399\end{array}$

$\begin{array}{llll}6 & 0.729922681 & 7.847443222 & -1.617769533\end{array}$

$\begin{array}{llll}1 & 0.945685592 & 9.746439437 & -2.629441797\end{array}$

6

1

1

6

6

6

7

6

7

6

6

5

6

6

6

6

6

9 $\begin{array}{lll}0.682537801 & 7.170433111 & -0.382238071\end{array}$

\subsection{5 \\ 7.412397133 \\ 1.763803890}

0.634260558

0.497739486

$-0.805425416$

1.627113052

$-1.000971210$

$-2.112844616$

1.472634280

3.047047717

$-2.354545139$

0.125215197

$7.279801931 \quad-2.540118001$

$5.682813998 \quad-0.333099024$

5.138165268

$-0.309246834$

$4.834299166 \quad-0.316627296$

$3.739014578 \quad-0.274097872$

$5.760529445 \quad-0.309666440$

3.429828059

$-0.278031453$

$5.115429157 \quad-0.333972887$

$3.471093296-0.256348350$

$2.698948589-0.259072963$

$-2.466067974$

7.226081073

$-0.336140982$

$-3.047757127$

$4.725291282 \quad-0.277386534$

2.718661436

2.83701898

$-0.269591818$

3.750662680

6.448393245

$-0.374407197$

3.698768971

3.88217100

$-0.303940775$

0.021226685

$1.854938489 \quad 0.918933200$

\section{9}

1$$
1
$$

(1)

(1)

1

1

(1)

1

6

6

6

6

$\begin{array}{lll}-2.095109515 & 7.722472617 & -1.240937752 \\ -4.121856590 & 4.846263514 & -0.268859297\end{array}$

$\begin{array}{llll}1 & 3.466207413 & 7.038255906 & -1.253959968\end{array}$

$\begin{array}{llll}1 & 4.835708836 & 6.294724723 & -0.405636088\end{array}$

$\begin{array}{llll}1 & 3.521213462 & 7.060397846 & 0.506413191\end{array}$

$\begin{array}{llll}1 & 4.769676358 & 3.735432175 & -0.308042899\end{array}$

$\begin{array}{llll}6 & 1.032569627 & 9.996731068 & -0.479860411\end{array}$

$\begin{array}{llll}1 & 0.190862389 & 11.966013664 & -0.280848202\end{array}$

$\begin{array}{llll}1 & 1.395389938 & 11.824090601 & -1.571858612\end{array}$

$\begin{array}{llll}6 & 3.547082112 & 11.703594137 & 0.090494397\end{array}$

$\begin{array}{llll}6 & 2.000751137 & 13.505620314 & 0.660799342\end{array}$

$\begin{array}{llll}6 & 4.493954987 & 12.187513184 & 1.196680759\end{array}$

$\begin{array}{llll}1 & 3.631838908 & 10.615416162 & -0.014252478\end{array}$

$\begin{array}{llll}6 & 2.967919182 & 13.963737049 & 1.762067575\end{array}$

$\begin{array}{llll}1 & 2.206300826 & 14.086838547 & -0.262466786\end{array}$

$\begin{array}{llll}1 & 5.540600681 & 12.034904392 & 0.917108475\end{array}$

$\begin{array}{llll}1 & 2.696636068 & 13.484022792 & 2.716628094\end{array}$

$\begin{array}{llll}7 & 2.147459031 & 12.049837562 & 0.432756440\end{array}$

$\begin{array}{llll}8 & 4.350520922 & 13.628273123 & 1.420011915\end{array}$

$\begin{array}{llll}1 & 3.846789214 & 12.164550384 & -0.873999622\end{array}$

$\begin{array}{llll}1 & 4.279189591 & 11.646159778 & 2.132094586\end{array}$

$\begin{array}{llll}1 & 2.947270178 & 15.051570954 & 1.879414022\end{array}$

$\begin{array}{llll}1 & 0.968544123 & 13.717608562 & 0.971292511\end{array}$ 


\begin{tabular}{|c|c|c|c|c|c|c|c|}
\hline 8 & 5.527230277 & -4.689228784 & -0.058271243 & 7 & -9.426216186 & -4.853386848 & -0.164781039 \\
\hline 8 & 7.481527738 & -2.803240518 & -0.058000842 & 1 & -9.237432414 & -5.242957291 & 0.763315448 \\
\hline 8 & -8.324096718 & -0.887816414 & -0.177078329 & 7 & -10.920284171 & -2.490178702 & -0.219802021 \\
\hline 8 & -6.860719373 & -3.177569222 & -0.148133304 & 1 & -11.134602597 & -1.750716263 & 0.456655126 \\
\hline 78 & 7.536249057 & -4.811908999 & 0.008713015 & 6 & -11.660697494 & -3.770106753 & 0.101492936 \\
\hline 7 & 7.634625542 & -6.912564085 & 0.101134985 & 6 & -11.823438020 & -3.920630485 & 1.629537721 \\
\hline 1 & 7.298941478 & -7.196514988 & 1.027510741 & 6 & -10.891305313 & -4.958560874 & -0.536006107 \\
\hline 7 & 9.630824262 & -4.958204547 & 0.066743563 & 6 & -12.476607425 & -5.274394113 & 1.99257428 \\
\hline 1 & 9.974897903 & -4.254524661 & 0.727095488 & 1 & -10.839822929 & -3.828784127 & 2.111730115 \\
\hline 6 & 9.052964664 & -7.379279633 & -0.134108976 & 6 & -11.519231535 & -6.313671279 & -0.132881913 \\
\hline 6 & 10.043214368 & -6.355192484 & 0.468773533 & 1 & -10.921807196 & -4.847922691 & -1.627447042 \\
\hline 6 & 9.313200065 & -8.801042903 & 0.437807284 & 6 & -11.685030334 & -6.461391585 & 1.398472464 \\
\hline 6 & 11.501944584 & -6.688564679 & 0.050546397 & 1 & -12.539084419 & -5.368612995 & 3.083935330 \\
\hline 6 & 10.809574469 & -9.037655143 & 0.796792333 & 1 & -10.910165085 & -7.132593869 & -0.540212309 \\
\hline 1 & 8.697321093 & -8.945148716 & 1.338205907 & 1 & -10.700537656 & -6.527062799 & 1.888468477 \\
\hline 6 & 11.741243828 & -8.217811891 & -0.122163967 & 1 & -11.148149058 & -2.141908597 & -1.156243944 \\
\hline 1 & 11.731971531 & -6.177321882 & -0.896404204 & 1 & -8.837212168 & -5.347788918 & -0.841191818 \\
\hline 1 & 11.040647864 & -10.107035631 & 0.718914403 & 1 & -12.439915544 & -3.094429687 & 2.011344096 \\
\hline 1 & 11.564545406 & -8.510758437 & -1.166961709 & 1 & -13.509554006 & -5.299453868 & 1.612209446 \\
\hline 1 & 12.189797060 & -6.280096200 & 0.802274858 & 1 & -12.196924601 & -7.406746949 & 1.618758761 \\
\hline 1 & 12.791180651 & -8.451601818 & 0.092144163 & 1 & -12.507128675 & -6.392162236 & -0.610259147 \\
\hline 1 & 10.994583461 & -8.754742645 & 1.842680939 & 1 & -12.661470893 & -3.738593850 & -0.356075424 \\
\hline 1 & 8.977385030 & -9.546906752 & -0.294334799 & 6 & -2.891110946 & 2.134153679 & -0.225612573 \\
\hline 1 & 9.947507953 & -6.391562678 & 1.561647672 & 6 & -4.234439235 & 1.856911606 & -0.214286160 \\
\hline 1 & 9.190099996 & -7.380161878 & -1.223369390 & 1 & -2.165984166 & 1.327877124 & -0.214328174 \\
\hline 1 & 6.989960227 & -7.292066143 & -0.598754437 & 1 & -4.931325349 & 2.696992554 & -0.226786090 \\
\hline 1 & 9.986285638 & -4.719594155 & -0.864934430 & 6 & -4.862449813 & 0.540690924 & -0.190703451 \\
\hline 78 & -8.843275216 & -2.830741643 & -0.171824788 & 6 & -6.285482325 & 0.465107871 & -0.190372651 \\
\hline
\end{tabular}




\begin{tabular}{llll}
6 & -4.117844374 & -0.672683562 & -0.172041291 \\
6 & -6.933214169 & -0.772054075 & -0.175088349 \\
1 & -6.885626741 & 1.372560454 & -0.204388290 \\
6 & -4.765351408 & -1.915627394 & -0.156170545 \\
1 & -3.032319487 & -0.642948331 & -0.171304422 \\
6 & -6.172037888 & -1.974813927 & -0.159016243 \\
1 & -4.201545048 & -2.844422023 & -0.143185615 \\
6 & 2.913661009 & 1.409383321 & -0.233653150 \\
6 & 4.151278755 & 0.818261896 & -0.213034623 \\
1 & 2.015566015 & 0.801544536 & -0.220623056 \\
1 & 5.028000381 & 1.468488022 & -0.221522356 \\
\hline 6 & 4.450601940 & -0.608535559 & -0.176909235 \\
6 & 5.816286047 & -1.013842817 & -0.139629387 \\
\hline 6 & 3.443467963 & -1.614911351 & -0.175924788 \\
6 & 6.156824148 & -2.367358997 & -0.099836657 \\
\hline 1 & 6.611595213 & -0.271398647 & -0.139109255 \\
6 & 3.782902544 & -2.974598320 & -0.138601354 \\
1 & 2.394939704 & -1.333290766 & -0.205074845 \\
\hline 1 & 5.136664939 & -3.360064532 & -0.099449559 \\
\hline 6.017835493 & -3.746189121 & -0.138119863
\end{tabular}




\begin{tabular}{rr}
\hline & \\
$\operatorname{Pt}(1)-\mathrm{N}(1)$ & 2.105 \\
$\operatorname{Pt}(1)-\mathrm{N}(2)$ & 2.104 \\
$\operatorname{Pt}(2)-\mathrm{N}(3)$ & 2.104 \\
$\operatorname{Pt}(2)-\mathrm{N}(4)$ & 2.100 \\
$\operatorname{Pt}(1)-\mathrm{O}(1)$ & 2.011 \\
$\operatorname{Pt}(1)-\mathrm{O}(2)$ & 2.012 \\
$\operatorname{Pt}(2)-\mathrm{O}(3)$ & 2.010 \\
$\operatorname{Pt}(2)-\mathrm{O}(4)$ & 2.013 \\
$\mathrm{~N}(1)-\mathrm{Pt}(1)-\mathrm{N}(2)$ & 83.24 \\
$\mathrm{~N}(3)-\operatorname{Pt}(2)-\mathrm{N}(4)$ & 84.43 \\
$\mathrm{O}(1)-\mathrm{Pt}(1)-\mathrm{O}(2)$ & 84.96 \\
$\mathrm{O}(3)-\mathrm{Pt}(2)-\mathrm{O}(4)$ & 84.88 \\
$\mathrm{~N}(1)-\mathrm{Pt}(1)-\mathrm{O}(1)$ & 95.64 \\
$\mathrm{~N}(2)-\mathrm{Pt}(1)-\mathrm{O}(2)$ & 96.15 \\
$\mathrm{~N}(3)-\mathrm{Pt}(2)-\mathrm{O}(3)$ & 95.60 \\
$\mathrm{~N}(4)-\mathrm{Pt}(2)-\mathrm{O}(4)$ & 96.25 \\
\hline
\end{tabular}

\section{REFERENCES}

(S1) Skehan, P.; Storeng, R.; Scudiero, D.; Monks, A.; McMahon, J.; Vistica, D.; Warren, J. T.; Bokesch, H.; Kenney, S.; Boyd, M. R. New Colorimetric Cytotoxicity Assay for AnticancerDrug Screening. J. Natl. Cancer Inst. 1990, 82, 1107-1112.

(S2) Wang, H.; Joseph, J. A. Quantifying Cellular Oxidative Stress by Dichlorofluorescein Assay Using Microplate Reader. Free Radicals Biol. Med. 1999, 27, 612-616.

(S3) (a) Walker, N.; Stuart, D. An empirical method for correcting diffractometer data for absorption effects. Acta Crystallogr., Sect. A: Found. Crystallogr. 1983, 39, 158-166. (b) Sheldrick, G. M. Acta Crystallogr., Sect. C: Struct. Chem. 2015, 71, 3-8. 
(S4) Farrugia, L. WinGX and ORTEP for Windows: an update. J. Appl. Crystallogr. 2012, 45, 849-854.

(S5) Frisch, M. J.; Trucks, G. W.; Schlegel, H. B.; Scuseria, G. E.; Robb, M. A.; Cheeseman, J. R.; Scalmani, G.; Barone, V.; Mennucci, B.; Petersson, G. A.; Nakatsuji, H.; Caricato, M.; X. Li, H.P. Hratchian, A. F. Izmaylov, J. Bloino, G. Zheng, J. L. Sonnenberg, M. Hada, M. Ehara.; Toyota, K.; Fukuda, R.; Hasegawa, J.; Ishida, M.; Nakajima, T.; Honda, Y.; Kitao, O.; Nakai, H.; Vreven, T.; Montgomery Jr, J. A.; Peralta, J. E.; Ogliaro, F.; Bearpark, M.; Heyd, J. J.; Brothers, E.; Kudin, K. N.; Staroverov, V. N.; Kobayashi, R.; Normand, J.; Raghavachari, K.; Rendell, A.; Burant, J.C.; Iyengar, S. S.; Tomasi, J.; Cossi, M.; Rega, N.; Millam, J. M.; Klene, M.; Knox, J. E.; Cross, J. B.; Bakken, V.; Adamo, C.; Jaramillo, J.; Gomperts, R.; Stratmann, R. E.; Yazyev, O.; Austin, A. J.; Cammi, R.; Pomelli, C.; Ochterski, J. W.; Martin, R. L.; Morokuma, K.; .Zakrzewski, V. G.; Voth, G. A.; Salvador, P.; Dannenberg, J. J.; Dapprich, S.; Daniels, A. D.; Farkas, Ö.; Foresman, J. B.; Ortiz, J. V.; Cioslowski J.; Fox, D. J. GAUSSIAN 09 (RevisionA.1), Gaussian, Inc., Wallingford, CT, 2009. 